\title{
Acute Humoral Xenograft Rejection: Destruction of the Microvascular Capillary Endothelium in Pig-to-Nonhuman Primate Renal Grafts
}

\author{
Akira Shimizu, Shane M. Meehan, Tomasz Kozlowski, Tomasz Sablinski, \\ Francesco L. lerino, David K.C. Cooper, David H. Sachs, and Robert B. Colvin \\ Department of Pathology (AS, SMM, RBC), Transplantation Biology Research Center (TK, TS, FLI, DKCC, DHS), \\ Massachusetts General Hospital/Harvard Medical School, Boston, Massachusetts
}

\begin{abstract}
SUMMARY: The major cause of xenograft loss beyond hyperacute rejection is a form of injury, traditionally termed delayed xenograft rejection (DXR), whose pathogenesis is unknown. Here we analyze the immunologic and morphologic features of DXR that develops in pig kidney xenografts transplanted into nonhuman primates. Kidneys from miniature swine were transplanted into cynomolgus monkeys $(n=14)$ or baboons $(n=11)$ that received regimens aimed to induce mixed chimerism and tolerance. No kidney was rejected hyperacutely. Morphologic and immunohistochemical studies were performed on serial biopsies, and an effort was made to quantify the pathologic features seen. The early phase of DXR (Days 0-12) was characterized by focal deposition of $\operatorname{lgM}$, IgG, C3, and scanty neutrophil and macrophage infiltrates. The first abnormality recognized was glomerular and peritubular capillary endothelial cell death as defined by in situ DNA nick-end labeling (TUNEL). Damaged endothelial cells underwent apoptosis and, later, frank necrosis. The progressive phase developed around Day 6 and was characterized by progressive deposition of IgM, IgG, C3, and prominent infiltration of cytotoxic T cells and macrophages, with a small number of NK cells. Thrombotic microangiopathy developed in the glomeruli and peritubular capillaries with TUNEL+ endothelial cells, platelet aggregation, and destruction of the capillary network. Only rare damaged arterial endothelial cells and tubular epithelial cells were observed, with rare endothelialitis and tubulitis. In the advanced phase of DXR, interstitial hemorrhage and infarction occurred. During the development of DXR, the number of TUNEL + cells increased, and this correlated with progressive deposition of antibody. The degree of platelet aggregation correlated with the number of TUNEL + damaged endothelial cells. We conclude that peritubular and glomerular capillary endothelia are the primary targets of renal DXR rather than tubular epithelial cells or arterial endothelium and that the earliest detectable change is endothelial cell death. DXR was characterized by progressive destruction of the microvasculature (glomeruli and peritubular capillaries) and formation of fibrin-platelet thrombi. Both cytotoxic cells and antibodies potentially mediate the endothelial damage in DXR; however, in this model, DXR is largely humorally mediated and is better termed "acute humoral xenograft rejection." (Lab Invest 2000, 80:815-830).
\end{abstract}

$A$ nimal donors are a potential solution to the critical shortage of organs for transplantation in humans. Pigs, including major histocompatibility complex (MHC)inbred miniature swine, are considered the likely source for clinical xenotransplantation (Cooper et al, 1991; Sachs, 1994), facilitated by modification of the donor by genetic engineering. However, normal porcine organs transplanted into primates are aggressively rejected by the recipient's immune system. Hyperacute rejection (HAR) occurs within minutes to hours after transplantation and is mediated by natural anti-Gal-1-3-Gal (Gal) antibody and complement activation (Daniels and Platt, 1997; Good et al, 1992). HAR can be prevented by

\section{Received December 23, 1999.}

Supported by grant from the National Institutes of Health PO1-HL 18646 and a grant from BioTransplant, Inc.

Current affiliation for SMM is Department of Pathology, University of Chicago, Chicago, Illinois.

Address reprint requests to: Dr. R. B. Colvin, Department of Pathology, Massachusetts General Hospital, 55 Fruit Street (WRN 225), Boston, MA 02114. Fax:617-726-7533; colvin@helix.mgh.harvard.edu strategies such as depletion (or neutralization) of anti-Gal antibody, depletion or inhibition of complement, or the use of organs from pigs transgenic for human complement regulatory proteins (Lambrigts et al, 1998). However, even when HAR is avoided, the xenograft undergoes a delayed form of rejection, referred to as delayed xenograft rejection (DXR), which destroys the graft over a period of days and is now viewed as the major immunologic barrier to successful xenotransplantation (Bach et al, 1996; Lambrigts et al, 1998; Lawson and Platt, 1996). The immunologic basis (antibody, T cells, NK cells, and their target) of DXR is still uncertain.

At our center, a major effort is being made to induce immunological tolerance to pig tissues in nonhuman primates (cynomolgus monkeys and baboons) (Sachs and Sablinski, 1995; Sykes et al, 1994). HAR is overcome by depletion of natural antibody (Kozlowski et al, 1998; Sablinski et al, 1995, 1997). Our developing protocol, designed to promote tolerance, has been described in detail previously (Kozlowski et al, 1999; Sablinski et al, 1995, 1997). It includes depletion of anti-pig antibody, transient ablation of the recipient's cellular immunity, short courses of cyclosporine (CyA) and 15- 


\begin{tabular}{|c|c|c|c|c|c|c|}
\hline Animal & $\begin{array}{l}\text { Induction therapy } \\
\text { WBI (days, } \\
\text { SL-sublethal, } \\
\text { L-lethal) }\end{array}$ & $\begin{array}{l}\text { Removal of } \\
\text { natural antibody } \\
\text { (days) }\end{array}$ & $\begin{array}{c}\text { Pharmacologic } \\
\text { immunosuppressive } \\
\text { therapy }\end{array}$ & $\begin{array}{c}\text { Porcine } \\
\text { BMTx or } \\
\text { SLA Class II } \\
\text { gene } \\
\text { transduction }\end{array}$ & $\begin{array}{l}\text { Kidney } \\
\text { graft } \\
\text { survival } \\
\text { (days) }\end{array}$ & $\begin{array}{l}\text { Post-transplant day of } \\
\text { kidney biopsy } \\
\text { (grading of rejection) }\end{array}$ \\
\hline \multicolumn{7}{|l|}{ Group A } \\
\hline M1393 & & & & & 8 & $8(P-A)$ \\
\hline M1294 & None & day 0 & CYA, DSG & None & 7 & $7(\mathrm{P}-\mathrm{A})$ \\
\hline M1994 & & & & & 0 & $0(\mathrm{E})$ \\
\hline M3294 & & & & & 1 & $1(\mathrm{E})$ \\
\hline \multicolumn{7}{|l|}{ Group B } \\
\hline M1094 & $\begin{array}{l}\text { WBI (day-6, SL), } \\
\text { ATG }\end{array}$ & & & & 15 & $15(\mathrm{E})$ \\
\hline M1194 & $\begin{array}{l}\text { WBI (day-6, SL), } \\
\text { ATG }\end{array}$ & & & & 0 & $0(\mathrm{E})$ \\
\hline M1594 & $\begin{array}{l}\text { WBI (day-6, SL), } \\
\text { ATG }\end{array}$ & & & & 12 & $12(A)$ \\
\hline M2094 & $\begin{array}{l}\text { WBI (day-6, SL), } \\
\text { TI, ATG }\end{array}$ & & & & 2 & $2(\mathrm{E})$ \\
\hline M4094 & $\begin{array}{l}\text { WBI (day-6, SL), } \\
\text { TI, ATG }\end{array}$ & & & & 0 & $0(\mathrm{E})$ \\
\hline M3394 & $\begin{array}{l}\text { WBI (day-6, SL), } \\
\text { TI, ATG }\end{array}$ & day 0 & CYA, DSG & BMTx & 10 & $10(P)$ \\
\hline M3694 & $\begin{array}{l}\text { WBI (day-6, SL), } \\
\text { TI, ATG }\end{array}$ & & & & 10 & $10(\mathrm{E})$ \\
\hline M6593 & $\begin{array}{l}\text { WBI (day-6, SL), } \\
\text { TI. ATG }\end{array}$ & & & & 9 & $6(\mathrm{P}), 8(\mathrm{P}), 9(\mathrm{P})$ \\
\hline M1195 & $\begin{array}{l}\text { WBI (day-6, SL), } \\
\text { TI, ATG }\end{array}$ & & & & 7 & $7(\mathrm{~A})$ \\
\hline M0894 & $\begin{array}{l}\text { WBI (day-3, SL), } \\
\text { TI, ATG }\end{array}$ & & & & 12 & $12(\mathrm{E})$ \\
\hline B94-107 & $\begin{array}{l}\text { WBI (day-6, SL), } \\
\text { TI, ATG }\end{array}$ & & & & 9 & $0(N), 5(E), 8(E), 9(P)$ \\
\hline B55-126(1) & $\begin{array}{l}\text { WBI (day-6, SL), } \\
\text { TI, ATG }\end{array}$ & & & & 11 & $\begin{array}{l}0(\mathrm{~N}), 6(\mathrm{P}), 7(\mathrm{P}), \\
11(\mathrm{~A})\end{array}$ \\
\hline \multicolumn{7}{|l|}{ Group C } \\
\hline B75-37 & $\begin{array}{l}\text { WBI (day-22, SL), } \\
\text { TI, ATG }\end{array}$ & day $-6,0$ & CYA, DSG, MMF & & 6 & $0(\mathrm{~N}), 2(\mathrm{E}), 6(\mathrm{P})$ \\
\hline B55-125 & $\begin{array}{l}\text { WBI (day-22, SL), } \\
\text { TI, ATG }\end{array}$ & day $-6,0$ & CYA, DSG, MMF & BMTx & 3 & $0(N), 3(E)$ \\
\hline B55-126(2) & $\begin{array}{l}\text { WBI (day-20, SL), } \\
\text { TI, ATG }\end{array}$ & day $-14,0$ & CYA, DSG & & 14 & $\begin{array}{l}0(\mathrm{~N}), 2(\mathrm{E}), 5(\mathrm{E}), 9(\mathrm{P}), \\
\quad 14(\mathrm{~A})\end{array}$ \\
\hline B94-105 & $\begin{array}{l}\text { WBI (day-351, } \\
\text { SL), TI, ATG }\end{array}$ & day $-3,-2,0,4$ & CYA, BQR & & 6 & $0(N), 6(A)$ \\
\hline \multicolumn{7}{|l|}{ Group D } \\
\hline B75-13 & $\begin{array}{l}\text { WBI (day-104, } \\
\text { SL), TI, ATG }\end{array}$ & day $-7,-5,-2,0$ & $\begin{array}{l}\text { CYA, DSG, MMF, } \\
\text { sCR1 }\end{array}$ & SLA & 8 & $0(\mathrm{~N}), 8(\mathrm{P})$ \\
\hline B75-18 & WBI (day-111, L) & day $-7,-5,-2,0$ & $\begin{array}{l}\text { CYA, DSG, MMF, } \\
\text { SCR1 }\end{array}$ & SLA & 12 & $0(\mathrm{~N}), 12(\mathrm{~A})$ \\
\hline B74-34 & WBI (day-111, L) & day $-7,-5,-2,0$ & $\begin{array}{l}\text { CYA, DSG, MMF, } \\
\text { SCR1 }\end{array}$ & $\mathrm{Neo}$ & 13 & $0(\mathrm{~N}), 13(\mathrm{~A})$ \\
\hline B116-26 & WBI (day-111, L) & day $-7,-5,-2,0$ & $\begin{array}{l}\text { CYA, DSG, MMF, } \\
\text { SCR1 }\end{array}$ & SLA & 7 & $0(\mathrm{~N}), 7(\mathrm{P})$ \\
\hline B17-60 & WBI (day-111, L) & day $-7,-5,-2,0$ & CYA, DSG, MMF, CVF & Neo & 6 & $0(\mathrm{~N}), 6(\mathrm{P})$ \\
\hline
\end{tabular}

Animal: M, cynomolgus monkey; B, baboon.

Induction therapy: WBI, whole body irradiation (sublethal: 300cGy, lethal: 900cGy); TI, thymic irradiation (700cGy at day -1); ATG, anti-thymocyte globulin (50 $\mathrm{mg} / \mathrm{kg} /$ day; days $-3,-2,-1)$.

Removal of natural antibodies: Hemoperfusion through a pig liver or an aGal immunoaffinity column, or apheresis and plasma perfusion through an aGal immunoaffinity column.

Pharmacologic immunosuppressive therapy: CYA, cyclosporine A $15 \mathrm{mg} / \mathrm{kg} /$ day (day 0 to day 28); BQR, brequinqr $5 \mathrm{mg} / \mathrm{kg} /$ day (day -2 to day 11 ); MMF, mycophenolate mofetil $40 \mathrm{mg} / \mathrm{kg} /$ day (day 0 to day 14); DSG, 15-deoxyspergualin $6 \mathrm{mg} / \mathrm{kg} /$ day (day 0 to day 14); sCR1, soluble complement receptor-1, 12.5 or 25 $\mathrm{mg} / \mathrm{kg} /$ day (day 0 to day 8); CVF, cobra venom factor $0.20-0.25 \mathrm{mg} / \mathrm{kg} /$ day (day -1 to day 15 ).

Porcine bone marrow transplantation (BMTX), or SLA Class II gene (SLA) or neomycin-resistance gene (Neo) transduction: Porcine BMTx-donor pig cells infusion intravenously; SLA or Neo transduction-retrovirus mediated SLA class II DR gene (SLA) or neomycin-resistance gene (Neo) transfer into autologous bone marrow with reinfusion into recipient baboon.

Histological staging of delayed xenograft rejection: $N$, no rejection; E, early phase; $P$, progressive phase; $A$, advanced phase. 


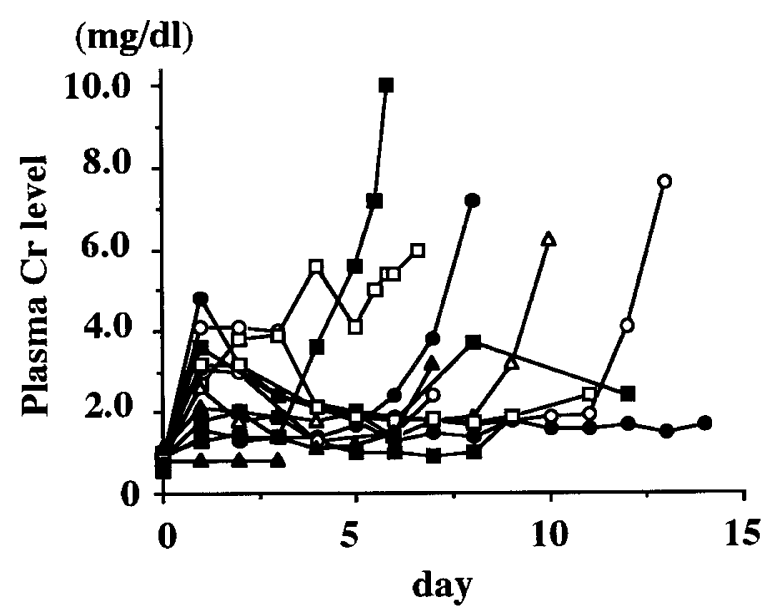

Figure 1

Serum creatinine levels in cynomolgus monkeys and baboons with lifesupporting porcine renal xenografts ( $n=12$, includes some of all groups). Recipients in which the native kidneys were not excised have been excluded.

deoxyspergualin (DSG), and donor-specific bone marrow infusion.

With this protocol, however, DXR develops with loss of graft function. The present study examines the morphological characteristics of DXR in this model, using serial biopsies from pig renal xenografts. We focused on antibody, cellular phenotype, platelet accumulation, and endothelial cell damage in DXR and conclude that the earliest feature is apoptosis and necrosis of the endothelium of the microvasculature (renal glomeruli and peritubular capillaries). Subsequent destruction of the microvascular capillary network with platelet aggregation is associated with graft loss.

\section{Results}

\section{Development of Delayed Xenograft Rejection}

Of the 25 kidney xenotransplants performed, none underwent HAR, but all were lost to delayed xenograft rejection (DXR) (Table 1). Table 1 summarizes the survival of the porcine renal xenografts. Sequential creatinine levels indicated that graft dysfunction typically developed between Days 6 and 14 (Fig. 1). Three animals had relatively good graft function when death occurred from systemic complications, which have been discussed elsewhere (Sablinski et al, 1997; Kozlowski et al, 1999).

The rejection process could be divided into three phases based on the extent of antibody deposition, cellular infiltration, and other morphological alterations. The first (early) phase of DXR was characterized by various degrees of antibody deposition in glomeruli and small vessels, an absence of cellular infiltration, and focal segmental glomerular "solidification" with endothelial swelling and loss of patent capillaries (Fig. 2A). Peritubular capillaries occasionally showed apoptotic nuclear changes. Glomerular and peritubular capillary endothelial nuclei were sometimes positive with the TdT-mediated dUTPbiotin nick-end labeling technique (TUNEL+; see below). No morphologic changes were evident in the small arteries. In the second (progressive) phase, both antibody deposition and cellular infiltration could be documented. Glomerular and peritubular capillary alterations progressed, with thrombi and focal interstitial hemorrhage (Fig. 2B). No changes were seen in the arteries. The third (advanced) phase was characterized by necrotizing arteritis and glomerulitis with multiple thrombi, and extensive interstitial hemorrhage and infarction (Fig. 2C). This sequence occurred in all of the xenografts, but with differing rates of progression (Table 1). To clarify the morphological characteristics of DXR and to help determine the mechanisms of injury, further studies of morphological markers were quantified in the early, progressive, and advanced phases, independent of the day on which the sample was taken.

\section{Deposition of Antibody and Complement}

Immunofluorescent analysis of the porcine renal xenografts showed a progressive deposition of $\operatorname{lgM}$, IgG,
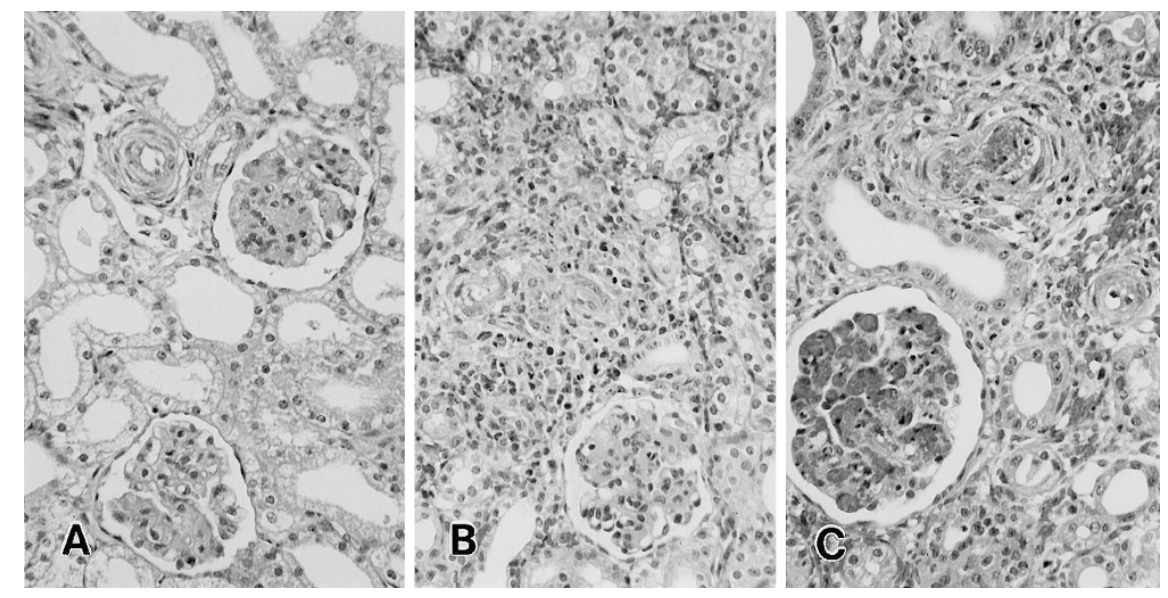

\section{Figure 2.}

Development of DXR seen in a porcine kidney transplanted into B55-126 (2) on Day 5 (the early phase) (A), Day 9 (the progressive phase) (B), and Day 14 (the advanced phase) (C). $A$ to $C$ : hematoxylin and eosin (H\&E) stain, $\times 250$. 
C3, and fibrin (Fig. 3, A to C). Immunohistochemistry for IgM (Fig. 3) and semiquantitative analysis (Fig. 4) revealed that no IgM was deposited immediately after reperfusion of the kidney. However, trace deposits of IgM began to accumulate in the glomeruli during the first day and gradually extended into the peritubular capillaries and arteries by Day 5 . Thereafter, progressive deposition of IgM was observed in these three structures. Deposition of IgG was similar. There was a more rapid and extensive IgM deposition in the kidneys of experimental Groups 1, 3, and 4 when compared with Group 2 (where the induction regimen immediately preceded kidney transplantation) (Fig. 4). Little or no C3 deposits were detected in the kidneys of the animals that received soluble complement receptor-1 (sCR1) or cobra venom factor (CVF).

\section{Characterization of the Cellular Infiltrate}

The early phase had few leukocytes, ie, polymorphonuclear leukocytes (PMNs) and macrophages, in the peritubular capillaries and glomeruli (Fig. 5A), but thereafter, a progressive mononuclear cells (MNC) infiltrate developed in the interstitium. Immunoperoxidase staining showed the cells expressed CD3, CD68, and/or GMP-17 (Fig. 5, B to D). Double staining for CD3 and GMP-17 cells showed that many GMP$17+$ cytotoxic cells were of $\mathrm{T}$ cell origin (Fig. 5E). Moreover, in all xenografts in the progressive phase, abundant infiltrating CD3+, CD4+ and CD8+ cells, and GMP-17+ MNCs were seen (Fig. 5, F to I). The extent of CD4+ cell infiltration was similar to or more prominent than that of CD8+ cells (Fig. 5, G and H). A relatively small number of $\mathrm{N} 42+\mathrm{NK}$ cells was identified (Fig. 5J).

Quantitative analyses of GMP-17+ PMN, GMP-17+ MNC, and CD68+ macrophage infiltration at various periods after transplantation are shown in Figures 6 and 7. Progressive infiltration of PMNs, cytotoxic MNCs, and macrophages was seen, especially in the peritubular interstitium and glomeruli (from Day 6) in the progressive and advanced phases of rejection. The infiltration of GMP-17+ cytotoxic MNCs in the kidneys of Experimental Groups 1, 3, and 4 (when nearly complete recovery of WBC and CD2+ cell counts in the peripheral blood occurred after induction regimen [Kozlowski et al, 1999]) was more prominent than that in the Group 2 kidneys (where the induction regimen was carried out immediately before kidney transplantation) (Fig. 6). The numbers of PMNs and macrophages did not differ significantly among the
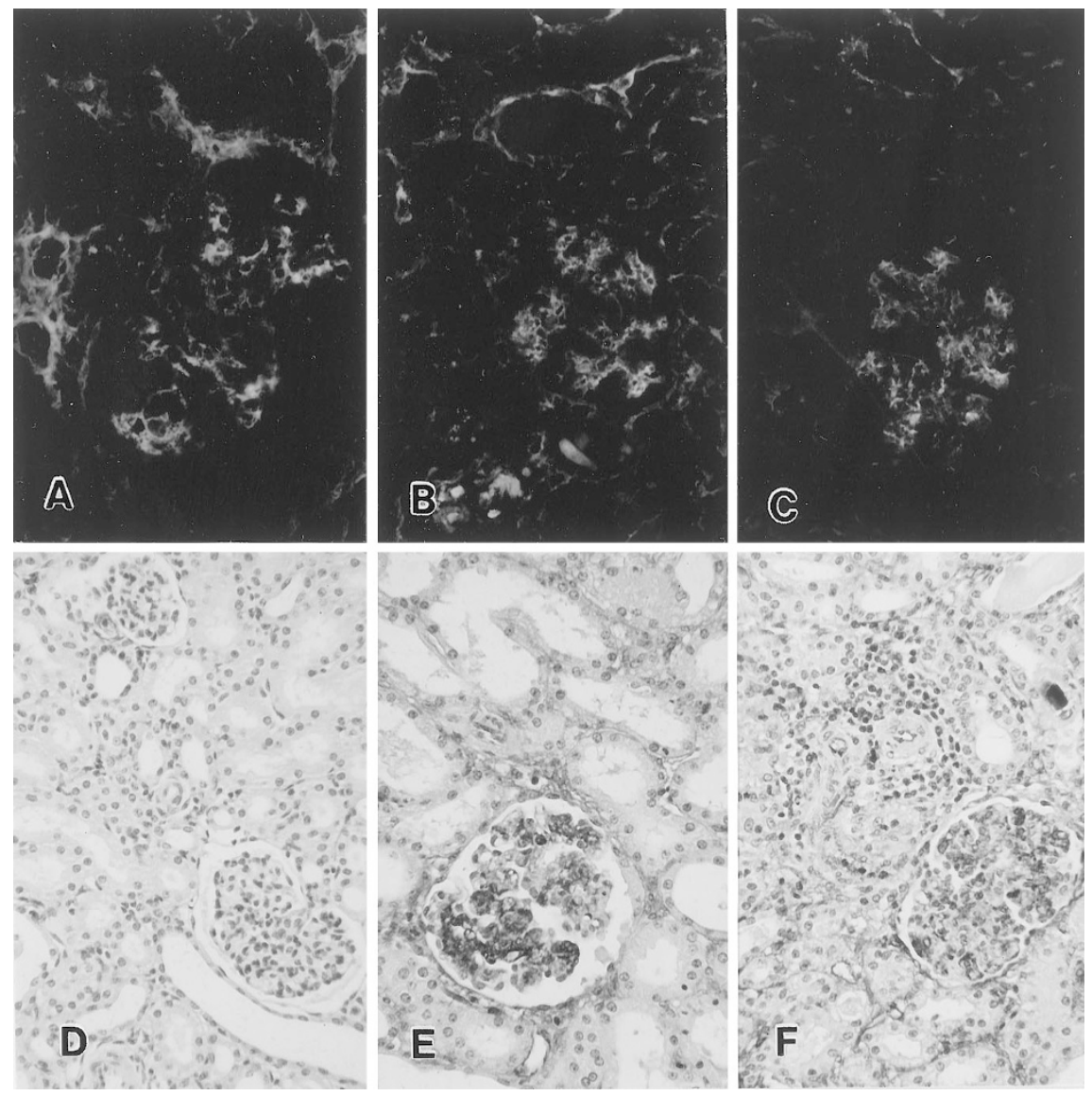

\section{Figure 3.}

Antibody and complement deposition in a renal xenograft, B55-126 (2). Immunofluorescent studies (Day 9) demonstrate moderate deposition of IgM (A), IgG (B), and C3 $(C)$ in the glomeruli, and weak focal deposition in the peritubular capillaries $(\times 300)$. Immunoperoxidase staining for IgM at 1 hour $(D)$, on Day $5(E)$, and on Day $9(F)$ shows progressive deposition in the glomeruli, peritubular capillaries, and arteries $(\times 250)$. 
A.

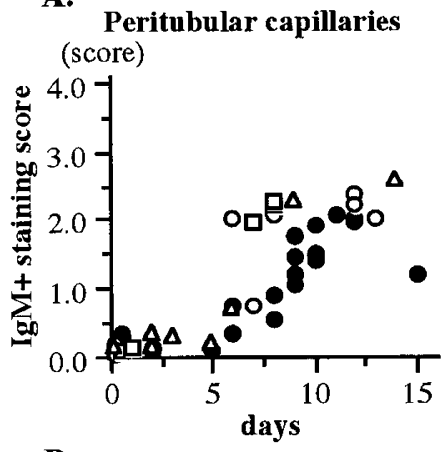

D.

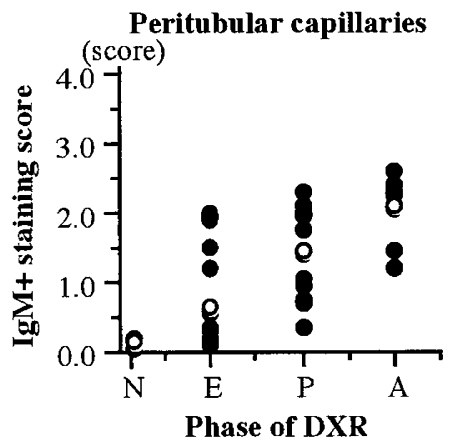

B.

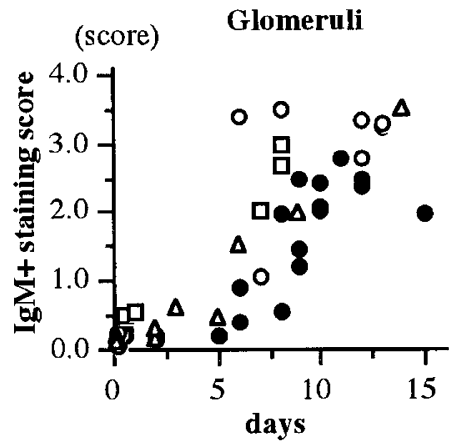

E.

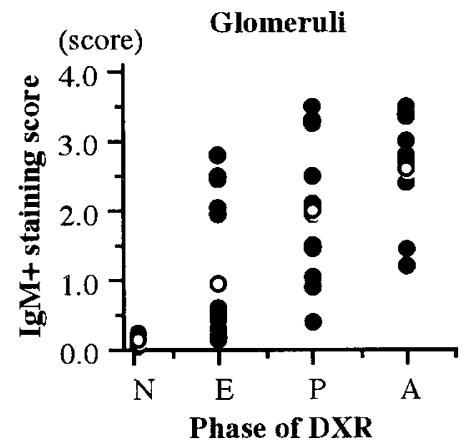

C.

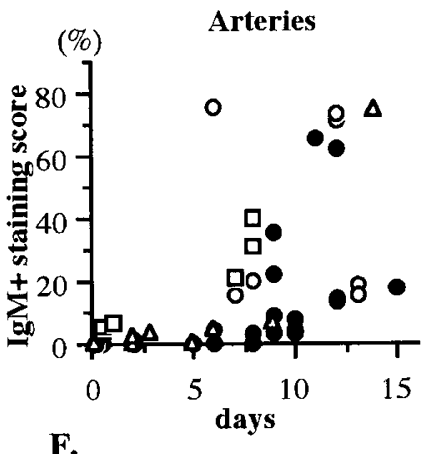

F.

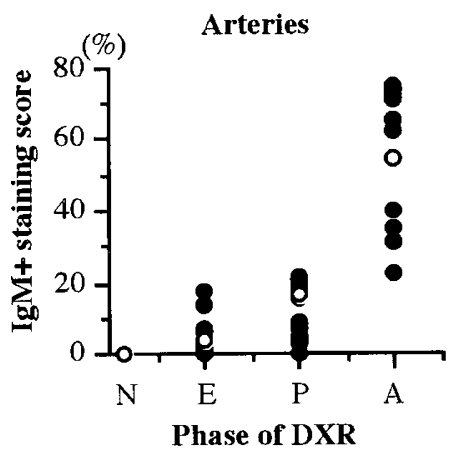

Figure 4.

Semiquantitative analysis of IgM staining in peritubular capillaries $(A, D)$, glomeruli $(B, E)$ and arteries $(C, F)$. $A$ to $C$, Progressive IgM deposition was observed from Day 5 and was more extensive in the Groups $1(\square), 3(\triangle)$ and $4(\bigcirc)$ recipients than in those of Group $2(\bullet)$. $D$ to $F$, Progressive IgM deposition in peritubular capillaries and glomeruli was seen from the early phase through the advanced phase (N, no rejection; E, early phase; P, progressive phase; and A, advanced phase). In the arteries, only minimal deposition of IgM occurred until the advanced phase. $O$ in $D$ to $F$ represents the mean value at each stage.
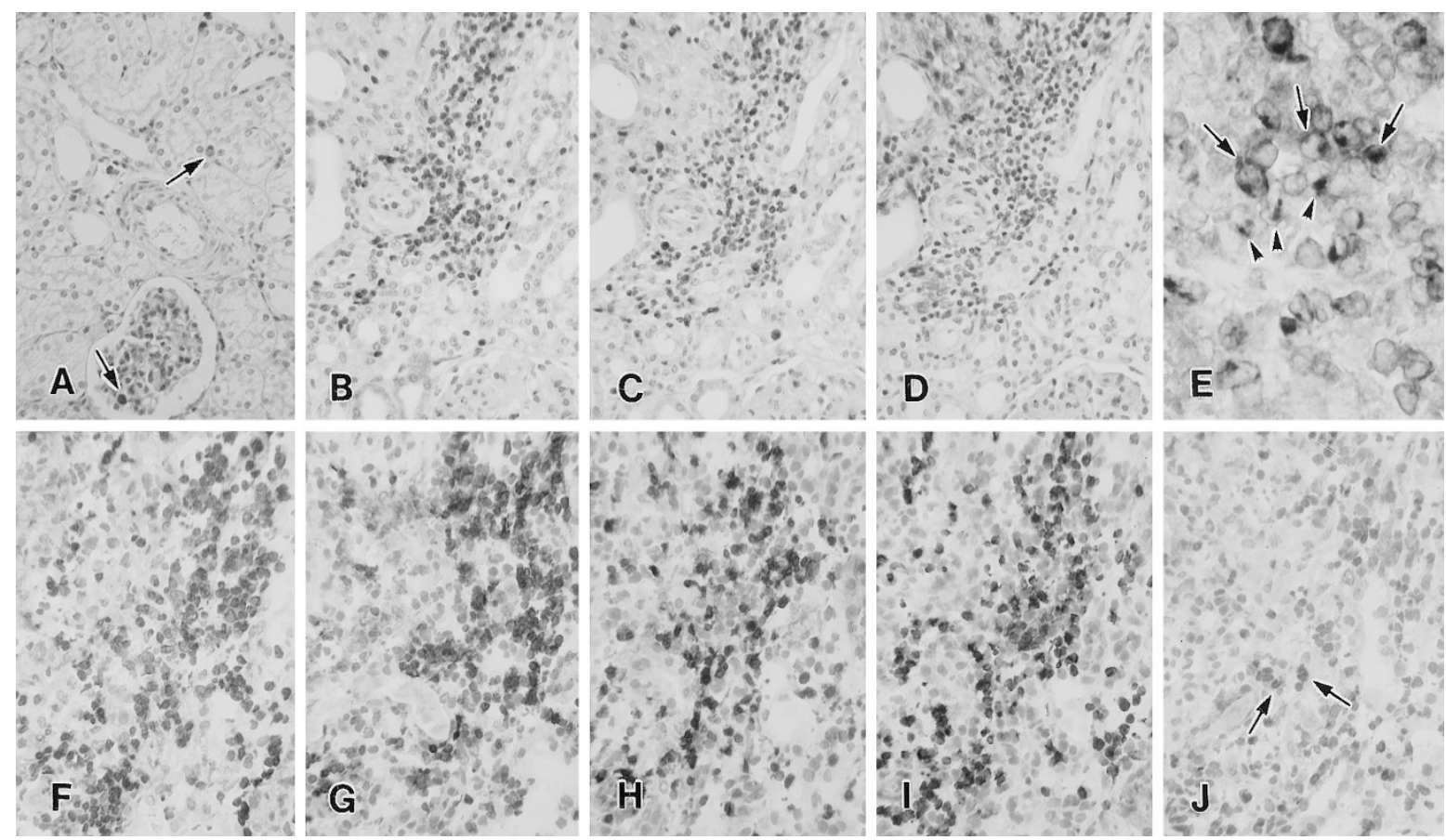

\section{Figure 5.}

The cellular infiltrates in DXR. $A$, In the early phase, few CD68+ macrophages (arrows) are seen in peritubular capillaries and glomeruli $(\times 250)$. In the progressive phase, prominent CD3 + T cells $(B)$, GMP-17+ cytotoxic MNCs $(C)$, and CD68+ macrophages $(D)$ are seen in the interstitium $(\times 250)$. E, Double staining for CD3 (brown) and GMP-17 (blue) on Day 7 in B55-126 (1) shows that many GMP-17+ cytotoxic cells are of CD3+ T cell origin (arrows). A few GMP-17+ mononuclear cells that do not stain for CD3 may be of NK cell origin $(\boldsymbol{\nabla})(\times 800)$. In the progressive phase, prominent CD3+ cells $(F)$, CD4+ cells $(G)$, CD8 + cells $(H)$, and GMP-17+ cytotoxic MNCs $(I$ are seen. In addition, a relatively small number of N42+ NK cells $(J)$ are observed $($ arrows). $F$ to $J: \times 500$. 


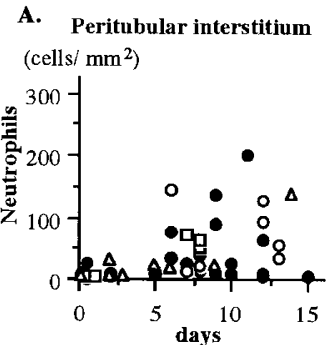

E.

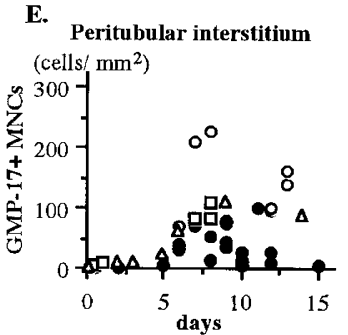

I. Peritubular interstitium (cells $/ \mathrm{mm}^{2}$ )

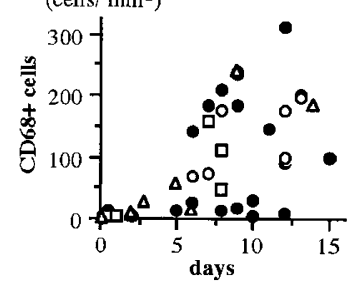

B.
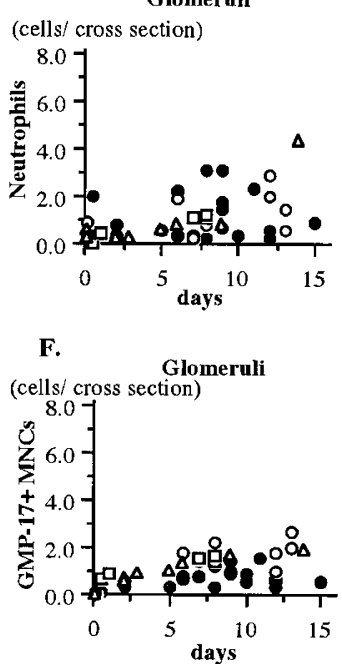

J.

Glomeruli

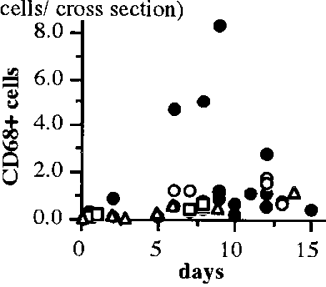

c.

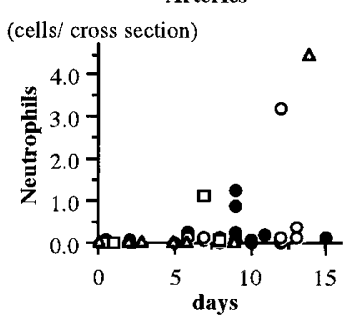

G.

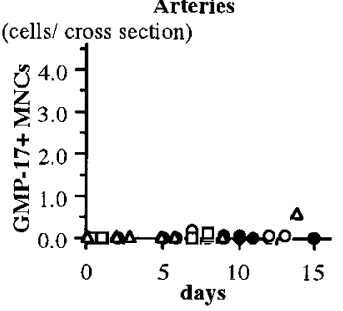

K. Arteries

(cells/ cross section)

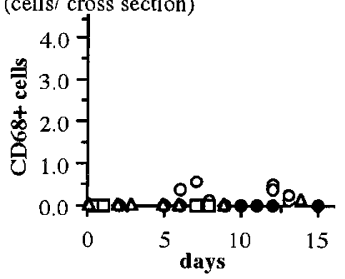

D.
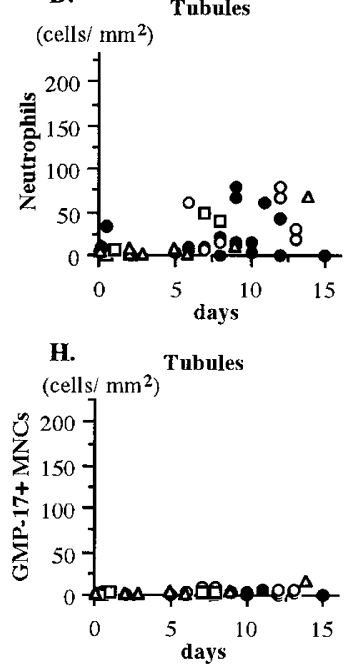

L.

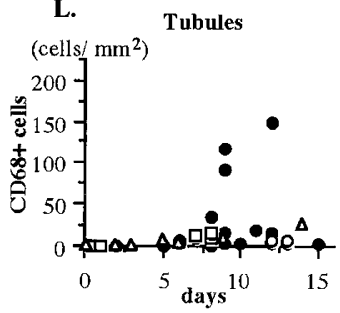

Figure 6.

The number of GMP-17+ PMNs $(A-D)$, GMP-17+ MNCs $(E$ to $H)$, and CD68+ macrophages ( $/$ to $L)$ infiltrating the peritubular interstitium $(A, E, I)$, glomeruli $(B$, $F, \mathcal{J}$, arteries $(C, G, K)$, and tubules $(D, H, L)$. In the peritubular interstitium and glomeruli, progressive GMP-17+ PMN, GMP-17+ MNC, and CD68+ macrophage infiltration develops from Day 6 . Although the numbers of PMNs and macrophages do not differ between each group, the frequency of GMP-17+ MNCs in the porcine kidneys in Groups $1(\square), 3(\triangle)$, and $4(\bigcirc)$ is higher than in those of Group $2(\bullet)$.

groups. Although there were small numbers of cytotoxic MNCs and macrophages infiltrating the arteries, a PMN infiltrate developed during the progressive and advanced phases of rejection (Fig. 7), and was associated with necrotizing arteritis. Only rare cytotoxic MNCs were seen infiltrating the tubules, and tubulitis was uncommon. However, PMN and macrophage infiltrates were observed in the tubules from the progressive to the advanced phases (Fig. 7) and were associated with extensive tubular necrosis.

\section{Endothelial Cell Injury, Platelet Aggregation, and Renal Capillary Destruction}

Graft injury was examined morphologically by electron microscopy and by the TUNEL method, which can detect damaged cells in the process of undergoing either apoptosis or necrosis (Mundle, 1995). From ultrastructural observations, both apoptotic and necrotic endothelial cells were seen in the peritubular and glomerular capillaries (Fig. 8). In the early phase, the first morphological abnormality recognized using the TUNEL method was glomerular and peritubular capillary endothelial labeling (Fig. 9A). From the progressive to the advanced phases, TUNEL + cells were prominent (Fig. 9, B and C).

The TUNEL+ damaged cells were quantitated at various times (Fig. 10). In the peritubular capillaries
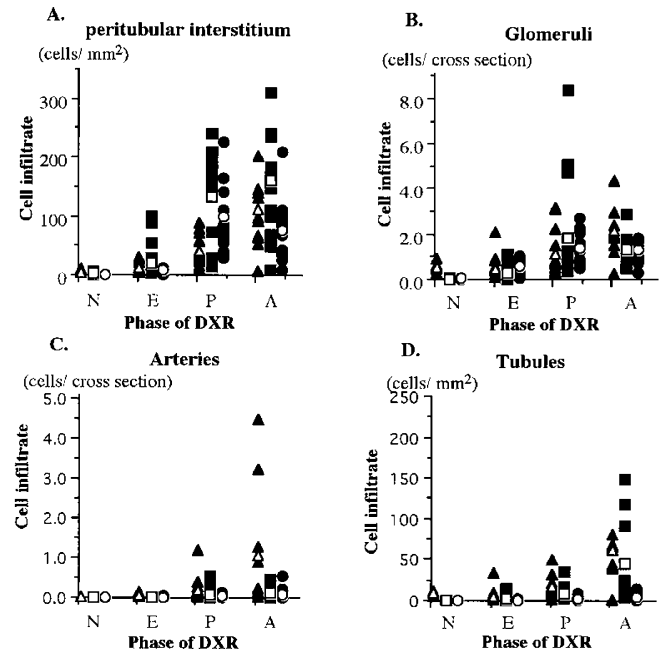

Figure 7.

The numbers of GMP-17+ PMN (४), GMP-17+ MNC $(\bullet)$, and CD68+ macrophages $(\square)$ infiltrating the peritubular interstitium $(A)$, glomeruli $(B)$, arteries $(C)$, and tubules $(D)$ in the various phases of DXR (N, no rejection; $\mathrm{E}$, the early phase; $\mathrm{P}$, the progressive phase; and $\mathrm{A}$, the advanced phase). Cytotoxic MNC, PMN, and macrophage infiltrate develops in the progressive and advanced phases in the interstitium and glomeruli, whereas minimal infiltration is seen in the arteries and tubules. In the advanced phase, a PMN infiltrate develops in arteries with necrotizing arteritis, and a PMN and macrophage infiltrate develops in tubules with tubular necrosis. $\triangle, O$, and $\square$ represent the mean values in each cells. 

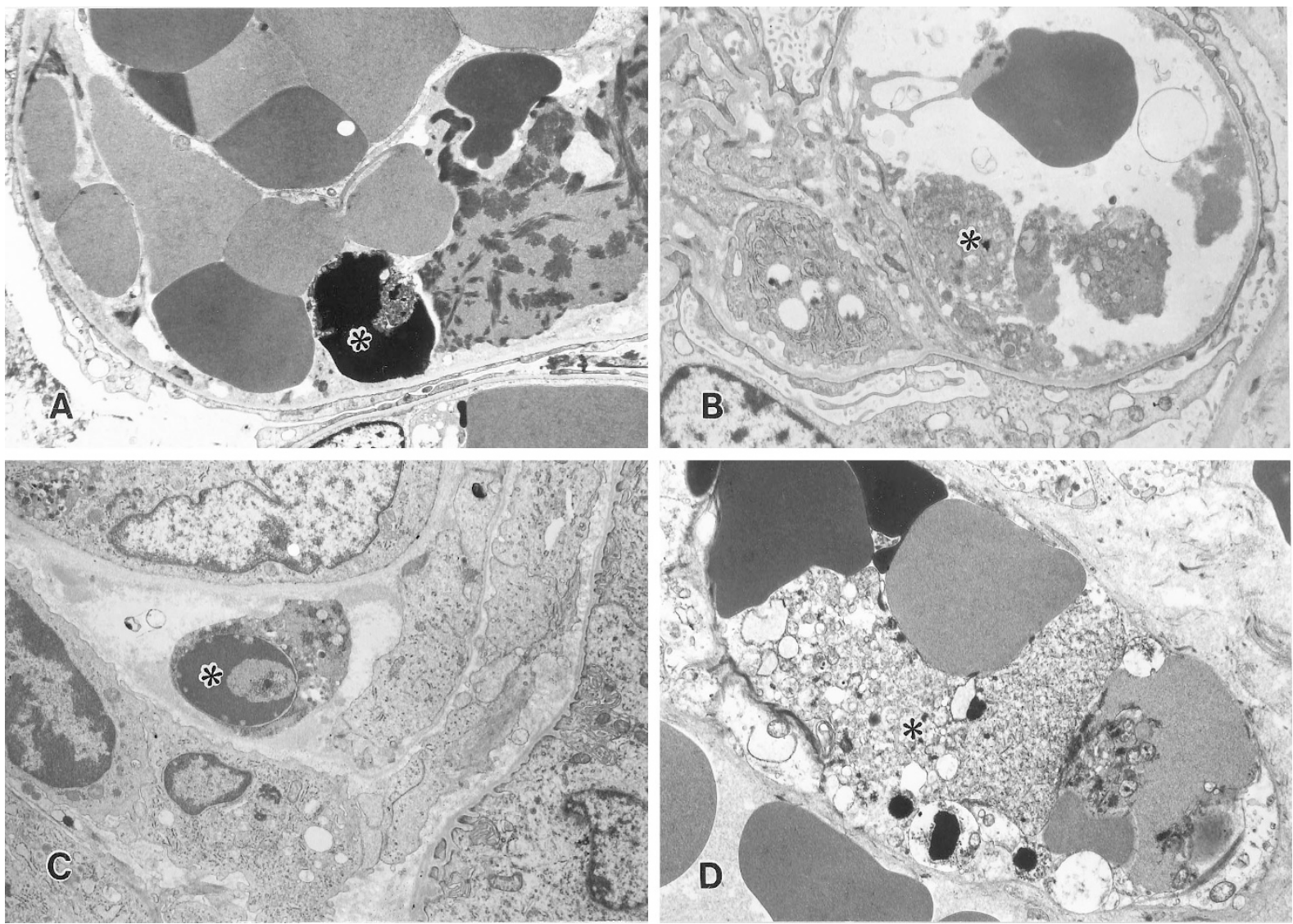

Figure 8 .

Endothelial cell apoptosis and necrosis in glomeruli and peritubular capillaries. Loss of endothelial cells is seen in glomerular capillaries with an apoptotic cell $\left({ }^{*}\right)$ (Day 5/B94-107, $\times 1900)(A)$ or necrotic cell debris $\left(^{*}\right)($ Day 8/B75-13, $\times 3400)(B)$. Glomerular mesangial and epithelial cells are almost intact, indicating that the capillary endothelium is the primary target in the glomeruli. Loss of endothelial cells with an apoptotic cell ( $\left.{ }^{*}\right)($ Day $5 / B 94-107, \times 4500)(C)$ or hydropic necrosis of endothelial cells $\left(^{*}\right)($ Day $6 / B 17-60, \times 3400)(D)$ are seen in peritubular capillaries.

and glomeruli, TUNEL+ cells were seen in the early phase and increased in number through the advanced phase. TUNEL+ cells were rarely observed in arteries and tubules, except in the advanced phase. With regards to the pathogenesis of endothelial cell injury in DXR, a significant correlation between the degree of IgM deposition and the number of TUNEL + damaged cells was seen in the peritubular capillaries, glomeruli, and arteries (Fig. 10, I to K). In contrast, there was no correlation between the numbers of GMP-17+ cytotoxic MNCs and TUNEL+ cells in the peritubular capillaries and arteries (Fig. 10, L and N), although there was mild correlation in the glomeruli (Fig. 10M).

Immunohistochemistry for CD62P and semiquantitative analysis of these samples showed progressive deposition of platelets in the xenografts (Fig. 9, D to F, and Fig. 11). Platelet aggregation was recognized in glomeruli in the early phase and gradually increased in the glomeruli and peritubular capillaries during the progressive and advanced phases. In the advanced phase, it was also seen in small arteries. A significant correlation was observed between the number of TUNEL + cells and the extent of platelet aggregation in the peritubular capillaries, glomeruli, and arteries (Fig. $11, G$ to I).
The status of the renal vasculature was examined by GS-IB4 immunohistochemistry for Gal expressed on pig endothelial cells. Along with the development of glomerular injury, GS-IB4 reactivity was lost from the glomerular capillary network, indicating the destruction of glomerular vasculature (Fig. 12B). These glomerular alterations were accompanied by TUNEL+ endothelial cells, multiple thrombi, marked deposition of IgM, and GMP-17+ MNCs (Fig. 12, A to D). The peritubular capillaries, identified by GS-IB4 staining, were absent around tubules with TUNEL+ endothelial cells. There was deposition of IgM and accumulation of GMP-17+ cytotoxic MNCs (Fig. 12, E to H). However, only rare endothelialitis and damaged endothelial cells were observed in the arteries, except in advanced DXR, in which the arteries were characterized by fibrinoid necrosis or endarteritis with TUNEL+ cells, thrombi, IgM deposition, as well as GMP-17+ PMN infiltration (Fig. 13, A to D). Only rare tubulitis was observed. Grouped TUNEL+ tubular cells were found in damaged tubules (Fig. $13 E)$, suggesting that tubular necrosis had occurred in the advanced phase. In the peritubular capillaries around necrotic tubules, many GMP-17+ PMNs were seen (Fig. 13F), but neither GMP-17+ cyto- 


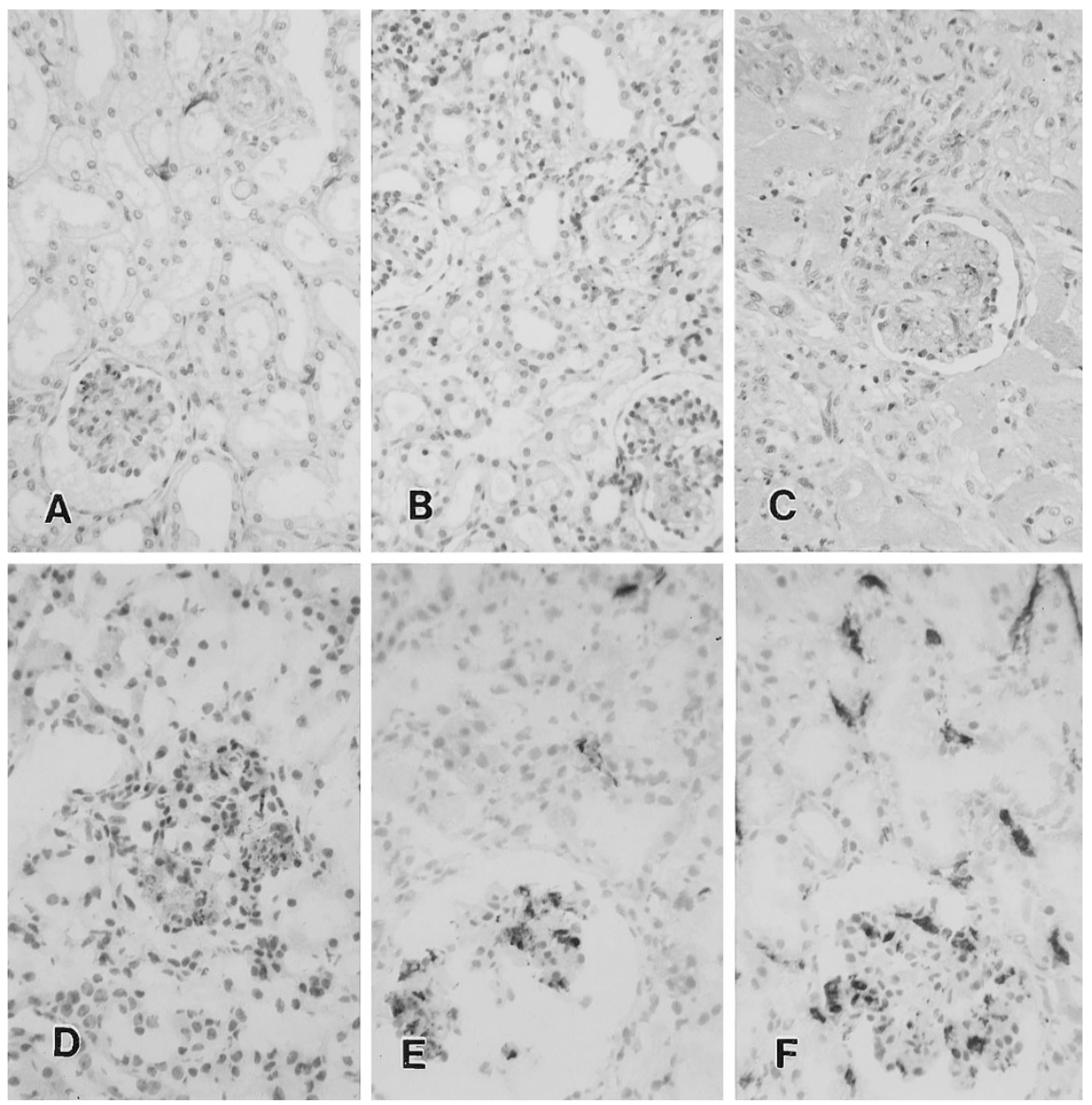

\section{Figure 9.}

Progressively increasing TUNEL+ damaged cells $(A$ to $C)$ and CD62P + platelet aggregation $(D$ to $F)$ in the early $(A, D)$, progressive $(B, E)$ and advanced $(C, F)$ phases. $A$ to $C$ : TUNEL method, $\times 250$. $D$ to $F: C D 62 P$ stain, $\times 400$. TUNEL+ peritubular and glomerular endothelial cells and glomerular platelet accumulation are present before a prominent infiltrate appears $(A, D)$.

toxic MNC infiltration nor IgM deposition was observed in these sites.

\section{Discussion}

The present study provides evidence that microvascular endothelial cell injury, characterized by endothelial cell apoptosis and necrosis, occurs from the early phase of DXR and increases during the later phases. It is associated with progressive deposition of antibody. Our results indicate that the primary target in DXR is the microvascular endothelium, rather than the arterial endothelium and tubular epithelial cells. Graft loss occurs in the advanced phase with widespread destruction of the capillary network and platelet accumulation.

In xenotransplantation, both antibody and cellular immunity are believed to be major factors in the pathogenesis of DXR (Bach et al, 1996; Lawson and Platt, 1996). However, the nature of the graft injury that occurs in DXR has not yet been well-characterized, although there is accumulating evidence that endothelial cell activation occurs (Bach et al, 1996; Hancock, 1997; Lawson and Platt, 1996; Palmetshofer et al, 1998). We observed by electron microscopy both endothelial cell apoptosis and necrosis. The TUNEL method can detect damaged cells in the process of both apoptosis and necrosis in tissue sections (Gavrieli et al, 1992; Mundle, 1995). This assay, therefore, has the advantage of allowing the detection of damaged cells induced by cell- and antibody-mediated immune injury. Indeed, prominent TUNEL+ cells were seen in thrombotic microangiopathic lesions in glomeruli and peritubular capillaries. More importantly, the first abnormality recognized in the porcine renal xenografts was endothelial labeling with TUNEL in the microvasculature, before DXR could be diagnosed morphologically. Our results demonstrate that the TUNEL assay is a sensitive method of assessing graft cell injury in both humoral- and cell-mediated rejection and may have a practical value in the diagnosis of early xenograft rejection.

In experimental or human renal allograft rejection, numerous TUNEL+ damaged cells are seen in tubules, glomeruli, peritubular capillaries, and small arteries, together with tubulitis, glomerulitis, and endothelialitis, associated with a T cell infiltrate (Meehan et al, 1997; Palmetshofer et al, 1998; Shimizu et al, 1997a; 1997b). In contrast to renal allograft rejection, only rare TUNEL + arterial endothelial cells and minimal TUNEL+ tubular cells were observed in DXR, 
A.

Peritubular capillaries

(cells/ $\mathrm{mm}^{2}$ )

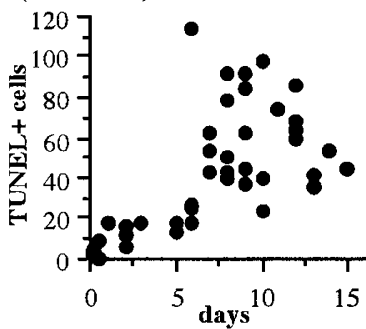

E. Peritubular capillaries (cells/ $\mathrm{mm}^{2}$ )

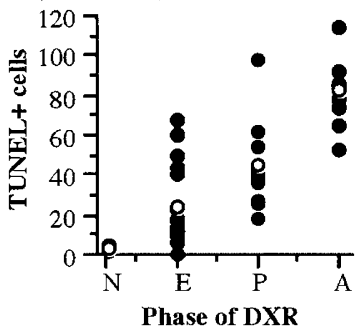

I.

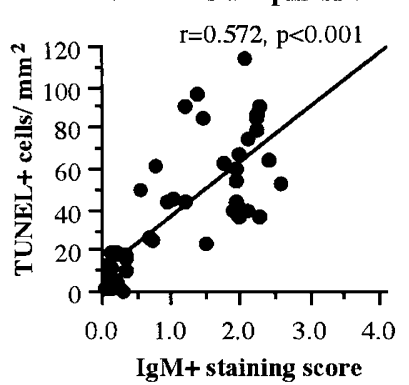

L.

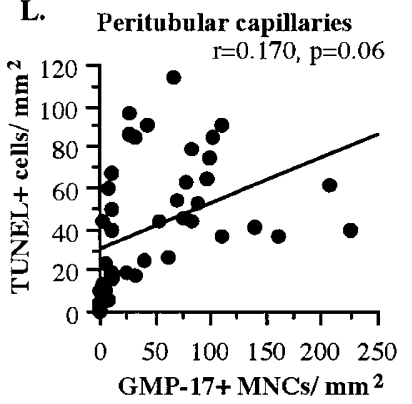

B.

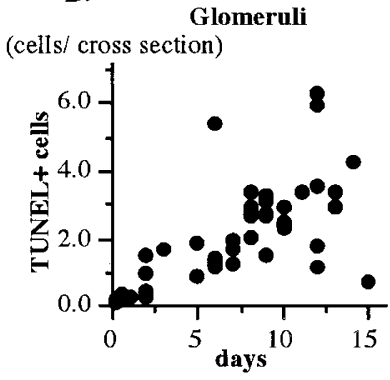

F.

(cells/ cross section)

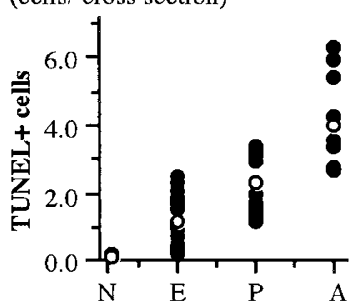

Phase of DXR
C.

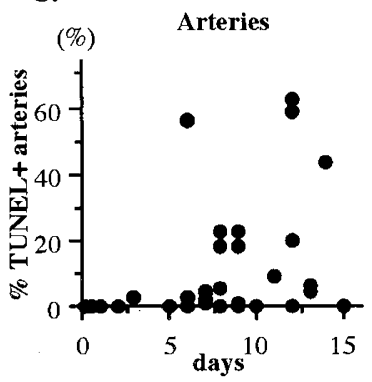

G.

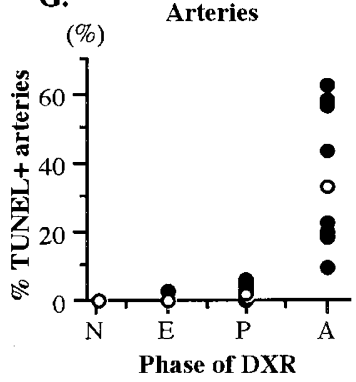

D. (cells $/ \mathrm{mm}^{2}$ ) Tubules

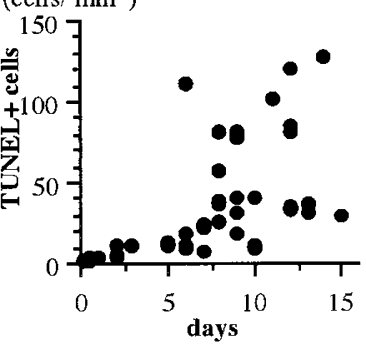

H.

(cells $/ \mathrm{mm}^{2}$ ) Tubules

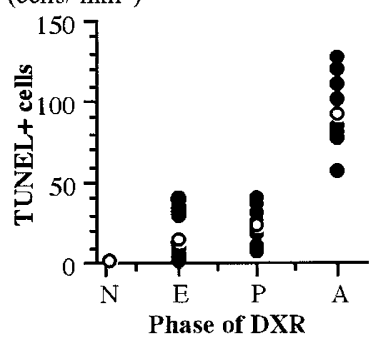

J.
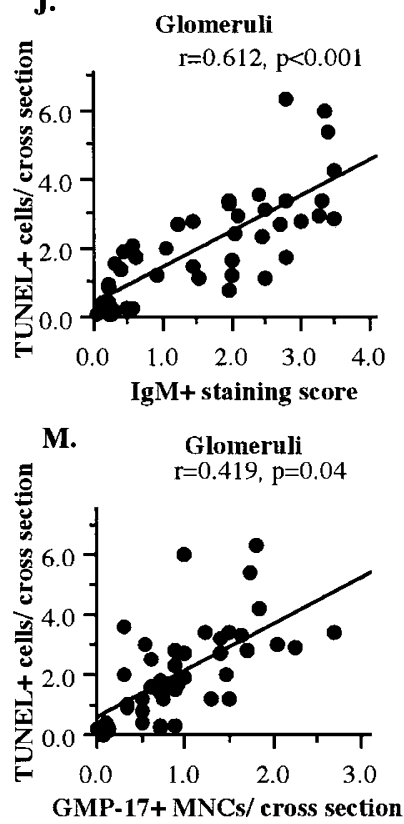

K. Arteries
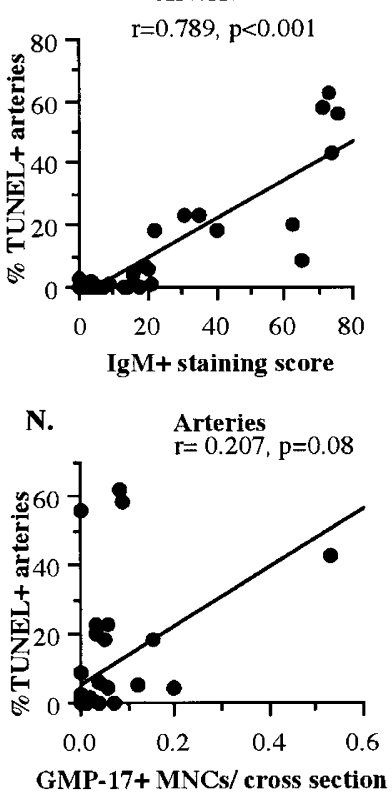

Figure 10.

The number of TUNEL + cells in the peritubular capillaries $(A, E)$, glomeruli $(B, F)$, arteries $(C, G)$, and tubules $(D, H)$, and correlation with graft IgM deposition $(I$ to $K$ ) or GMP-17+ graft infiltrating cytotoxic MNCs $(L$ to $M$ ). $A$ to $H$, TUNEL + cells in the peritubular capillaries and glomeruli are seen from Day 2 in the early phase, and are prominent in the progressive and advanced phases ( $E$ to $\mathrm{H}: \mathrm{N}$, no rejection, $\mathrm{E}$, the early phase; $\mathrm{P}$, the progressive phase; and $\mathrm{A}$, the advanced phase). Rare TUNEL+ cells are observed in arteries and tubules, except in advanced DXR. $\bigcirc$ in $E$ to $H$ represents the mean value in each stage. The number of TUNEL+ cells and the extent of $\mathrm{IgM}$ deposition correlate significantly by linear regression ( $/$ to $\mathrm{K}$ ); however, only weak correlation is seen between the numbers of TUNEL+ cells and GMP-17+ MNCs ( $L$ to $M$.

indicating that these cells are spared by DXR. In contrast, peritubular and glomerular capillary endothelia are primary targets of renal DXR. Indeed, GMP$17+$ cytotoxic MNCs infiltrated the peritubular capillaries, glomeruli, and interstitium, whereas there were only minimal infiltrates in the tubules and arteries, even in the progressive and advanced phases. The progressive deposition of antibody also occurred in the peritubular capillaries and glomeruli from the early phase.
In the kidney, endothelial cell injury can lead to thrombotic microangiopathy (Ballermann, 1998; Colvin, 1996). In the present study, endothelial cell death was associated with platelet aggregation as well as destruction of the vascular capillary network of the peritubular capillaries and glomeruli. Morphological thrombotic microangiopathy developed, with multiple platelet-fibrin thrombi. It has been reported that intravascular fibrin deposition and platelet activation can 
A.
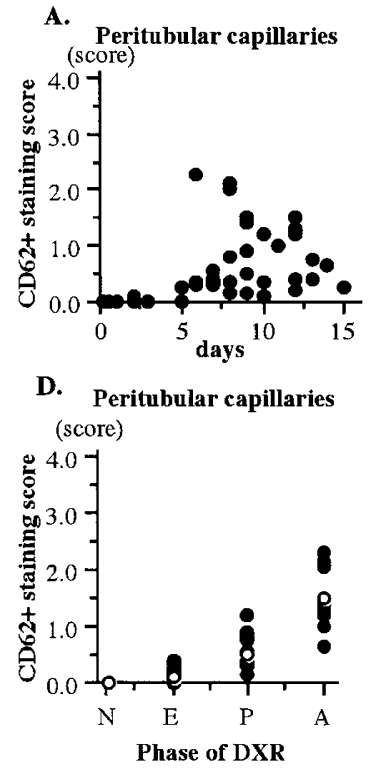

G.

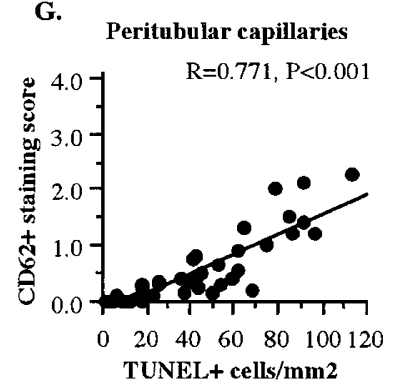

B.

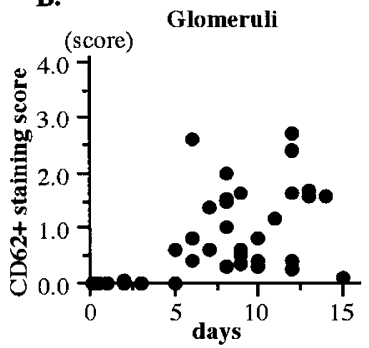

E.

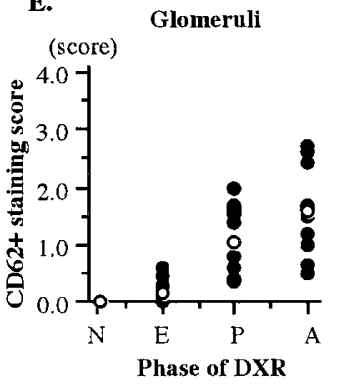

H.

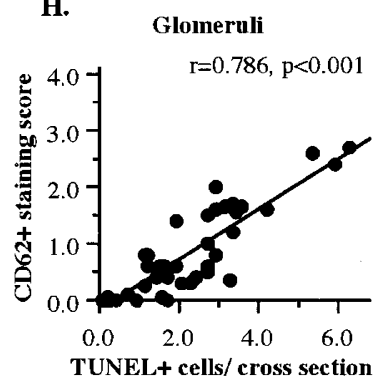

C.

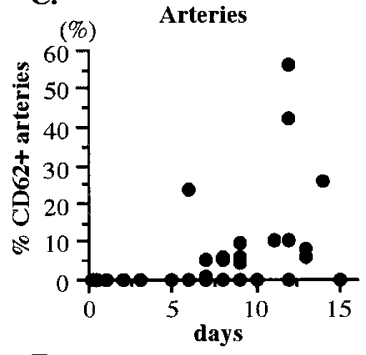

F.

Arteries
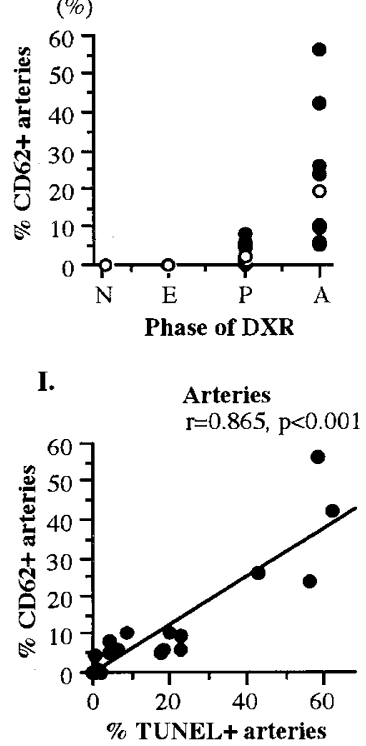

Figure 11.

Semiquantitative analysis of CD62P staining in peritubular capillaries $(A, D)$, glomeruli $(B, E)$ and arteries $(C, F)$, and correlation with the number of TUNEL + cells $(G$ to $)$. $A$ to $F$, Progressive platelet aggregation in glomeruli and peritubular capillaries is seen from Day 6 in the progressive phase, and develops through the advanced phase ( $D$ to $F: \mathrm{N}$, no rejection; $\mathrm{E}$, the early phase; $\mathrm{P}$, the progressive phase; and $\mathrm{A}$, the advanced phase). In arteries, minimal platelet aggregates are seen until the advanced phase. $O$ in $D$ to $F$ represents the mean value in each stage. $G$ to $I, A$ significant correlation is observed between the degree of platelet aggregation and the number of TUNEL+ cells .

develop in discordant porcine xenografts as a consequence of complement activation, inflammation, and the secondary development of a procoagulant state (Bach et al, 1996; lerino et al, 1998; Lawson and Platt, 1996; Robson et al, 1996; Saadi et al, 1995). Alternatively, vascular thrombosis may be promoted by cross-species molecular incompatibilities between activated primate coagulant factors and donor anticoagulant proteins expressed on the graft vasculature (Bach et al, 1996). Our results demonstrate that platelet aggregation is correlated with the number of TUNEL + endothelial cells, suggesting that endothelial cell death contributes to the in situ coagulopathy.

In view of the possibility that the overall rejection response to a discordant xenograft will be greater than that to an allograft, and will necessitate heavy immunosuppressive therapy, ongoing studies are progressing at our center towards the induction of immunological tolerance to miniature swine tissues in nonhuman primates by mixed lymphohematopoietic chimerism (Sachs and Sablinski, 1995; Sykes et al, 1994). The conditioning regimen includes transient ablation of the recipient's immune system and transplantation of donor bone marrow (BM) cells. This regimen leads to immunological tolerance to concordant xenografts in the rodent (rat-to-mouse) model (Sharabi et al, 1990; Sykes et al, 1994) and medium-term survival of concordant xenografts in nonhuman primates (baboonto-cynomolgus monkey) (Bartholomew et al, 1997). In the present study, however, even when combined with anti-pig antibody depletion by extracorporeal immunoadsorption (EIA), this regimen was not sufficient to induce tolerance to pig organs in nonhuman primates, and DXR developed within days.

A variety of observations suggest that it is the humoral immune response of the recipient that leads to DXR (Bach et al, 1996; Lawson and Platt, 1996; Lin et al, 1998). The present study showed progressive deposition of $\operatorname{lgM}$, IgG, and $\mathrm{C} 3$ in the glomeruli, peritubular capillaries, and arteries. Previous studies have demonstrated that, after EIA without kidney transplantation, anti-Gal IgM and IgG recover to pretreatment levels or higher by Day 7 (Kozlowski et al, 1998, 1999). No antibodies or minimal levels of antibody to pig antigens (other than anti-Gal) have been detected in primates after porcine kidney transplantation. These results suggest that progressive deposition of antibody is associated with return of circulating 

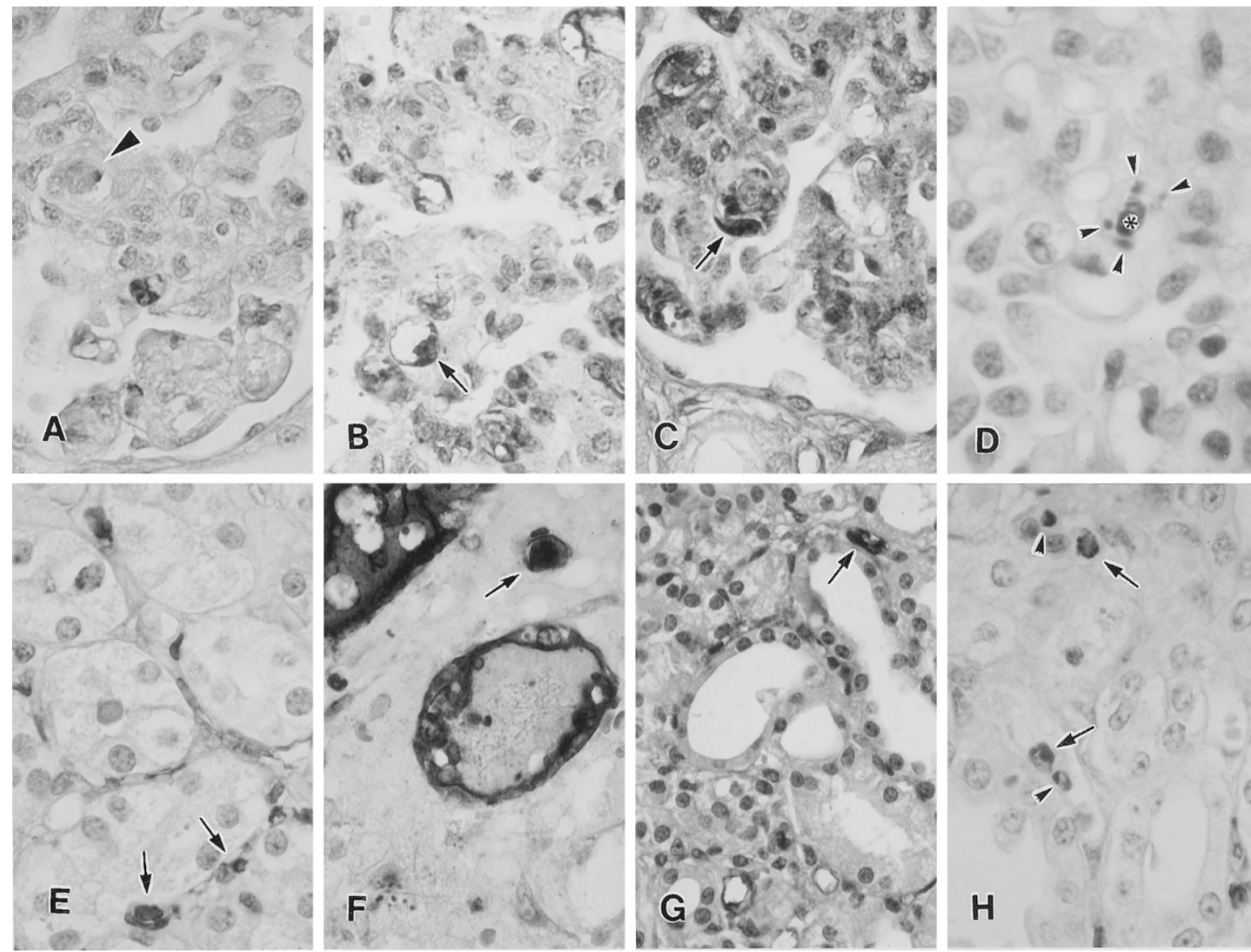

\section{Figure 12.}

The development of thrombotic microangiopathy in renal glomeruli $(A$ to $D)$ and peritubular capillaries ( $E$ to $H)$. The TUNEL stain shows the prominent TUNEL + cells (arrows) in glomerular $(A)$ and peritubular $(E)$ capillaries $(\times 800) ; \boldsymbol{\nabla}$ in $(A)$ indicates the thrombus. GS-IB4 stain shows loss of capillary lumina in the glomeruli $(B)$ or around tubules $(F)$, indicating destruction of the renal capillary network $(\times 800)$; (arrow) indicates the remaining GS-IB4+ capillaries. IgM deposition is seen in glomerli (capillaries and mesangium) $(C)$ and peritubular capillaries $(G)$ with damaged endothelial cells (arrow) (IgM stain, $\times 800)$. Infiltrating GMP-17+ cells in glomerular capillaries $\left(^{*}\right)(D)$ or peritubular capillaries $($ arrows $)(H)$ are in contact with apoptotic bodies $(\nabla)($ GMP-17 stain, $D: \times 1000, H: \times 800)$.

anti-Gal antibody. Significant correlation between the progressive deposition of IgM and the development of endothelial cell injury was observed in the present study. In the Group 4 animals, which received treatment with SCR-1 or CVF, DXR occurred despite minimal deposition of complement, suggesting that antibody deposition led to DXR with or without complement activation, although more typical and severe DXR is associated with the presence of complement activation. We therefore conclude that antibodies play an important role in the pathogenesis of DXR and suggest that DXR might be successfully prevented or treated by therapies aimed at the humoral immune response to porcine antigens.

However, cellular elements also appear to play a significant role in the development of DXR (Blakely et al, 1994; Candinas et al, 1996; Kobayashi et al, 1997; Leventhal et al, 1993). Some studies conclude that infiltrating cells consist primarily of macrophages and NK cells in rodents (Blakely et al, 1994; Candinas et al, 1996) and are T cell-independent, in view of the low number of $T$ cells in the infiltrates in the xenografted organs (Candinas et al, 1996). Others have also argued a role for macrophages and NK cells (Blakely et al, 1994; Candinas et al, 1996; Fryer et al, 1997; Kobayashi et al, 1997; Seebach and Waneck, 1997).

In the present study, the cellular response was characterized by a massive infiltration of $\mathrm{CD} 3+\mathrm{T}$ cells, together with a similarly intense macrophage infiltrate, and relatively small numbers of $\mathrm{N} 42+\mathrm{NK}$ cells. Many CD3+ GMP-17+ cytotoxic T cells were present in the infiltrate. Recent observations concerning human anti-pig cellular xenoreactivity support our findings (Auchincloss, 1994; Yamada et al, 1996). These studies demonstrated a human anti-pig, cellmediated cytotoxic response, involving CD8+ cells in cell-mediated cytotoxicity, as well as CD4 + cells as important mediators of macrophage, $\mathrm{T}$ cell, and $\mathrm{B}$ cell activation. Our results demonstrate that similar frequencies of CD4+ and CD8+ T cells infiltrated the graft in DXR, although CD8 $+\mathrm{T}$ cells predominate in allograft rejection (Colvin, 1995). This suggests that the Class II-restricted, T cell-mediated reactions have a role in DXR.

In summary, in our evolving regimen designed to promote tolerance in the pig-to-primate renal xenograft model, HAR can be overcome by anti-pig antibody depletion. However, with the return of 

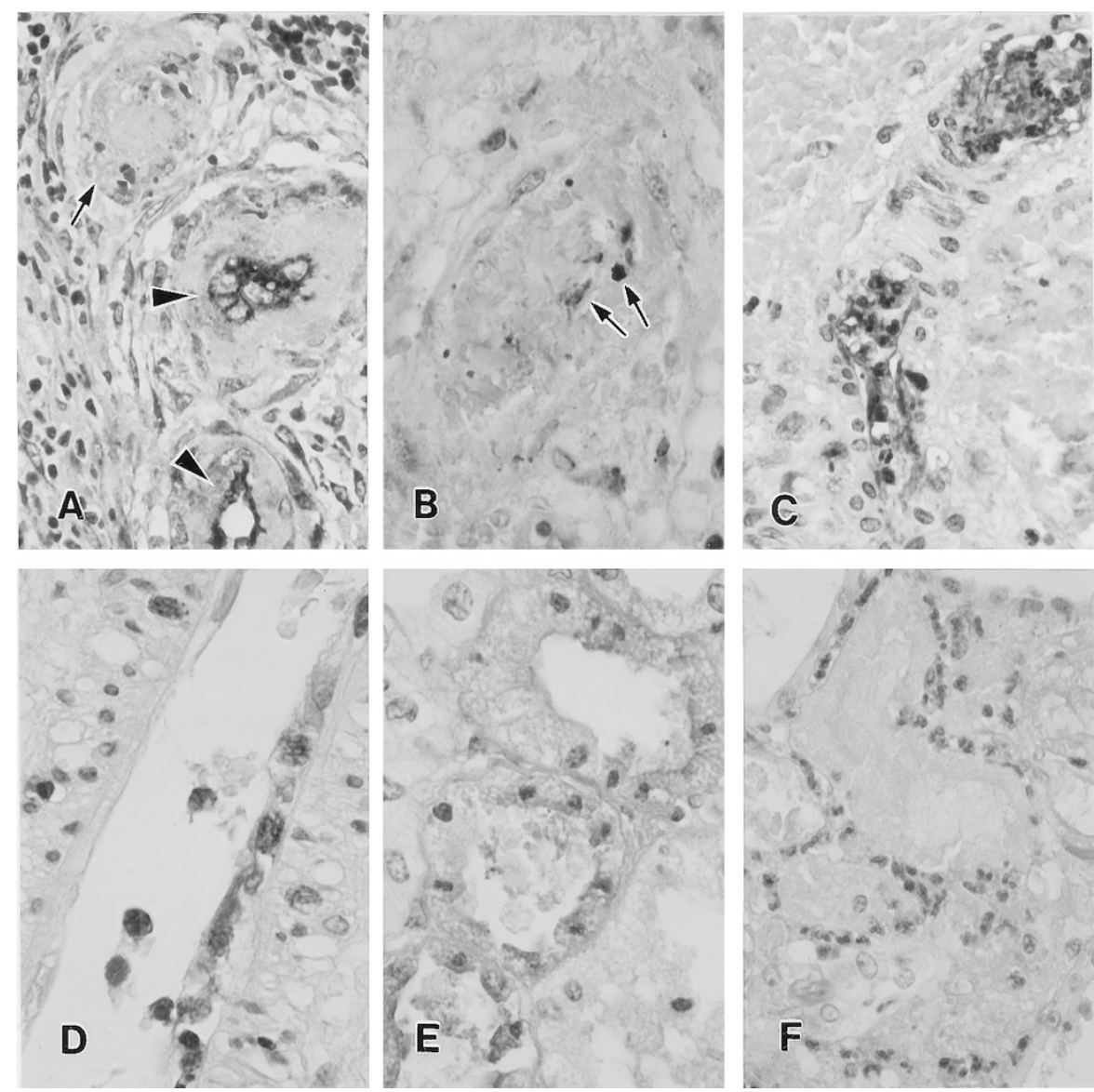

\section{Figure 13}

Arterial endothelial cell injury ( $A$ to $D)$ and tubular epithelial cell necrosis $(E, F)$ in the advanced phase. Loss of endothelial cells in a small artery (arrow) is recognized by GS-IB4 stain $(A)(\times 500)$, and with TUNEL + cells (arrows) $(B)$ (TUNEL method, $\times 800)$; arrowhead in $A$ indicates remaining endothelial cells in small arteries. Endarteritis is observed with IgM deposition $(\operatorname{lgM}$ stain, $\times 500)(C)$ and GMP-17+ PMNs $(D)(G M P-17$ stain, $\times 800)$. Grouped TUNEL+ tubular cells are seen in damaged tubules suggesting tubular epithelial cell necrosis (TUNEL method, $\times 500)(E$ ), and many GMP-17+ PMNs are found in peritubular capillaries with tubular necrosis, (GMP-17 stain, $\times 500)(F)$.

natural anti-Gal antibody to the recipient's circulation, DXR develops, resulting in graft failure. While the cytotoxic cell infiltrate might add to the severity of DXR, antibody would appear to play an important role in its pathogenesis in this model. Morphologically, DXR is characterized by the development of thrombotic microangiopathy, with endothelial cell apoptosis and necrosis, followed by destruction of the microvasculature and platelet aggregation. These features are quite similar to acute humoral allograft rejection in humans (Collins et al, 1999; Trpkov et al, 1996). We therefore prefer the term "acute humoral xenograft rejection" rather than DXR.

\section{Materials and Methods}

\section{Animals and Surgical Procedures}

Cynomolgus monkeys (Macaca fasicularis; Charles River Laboratories, Wilmington, Massachusetts), weighing 5 to $8 \mathrm{~kg}$, or baboons (Papio anubis; Biological Resources, Houston, Texas), weighing 8 to $15 \mathrm{~kg}$, were used as recipients. Bone marrow and kidney donors were from the Massachusetts General Hospital (MGH) herd of MHC-inbred miniature swine (Charles River Laboratories). One miniature swine also provided a liver for antibody adsorption from the recipient by hemoperfusion.

The surgical techniques of harvesting donor organs, recipient splenectomy, and kidney transplantation, as well as details of supportive care, have been described previously (lerino et al, 1998; Kozlowski et al, 1999; Sablinski et al, 1995, 1997). Open kidney biopsies were taken on several posttransplant days and at the time when the graft was rejected or the animal died. Graft function was monitored by plasma creatinine $(\mathrm{Cr})$ and blood urea nitrogen (BUN) levels. All experiments were conducted according to the NIH Guide for the Care and Use of Laboratory Animals and were approved by the MGH Subcommittee on Research Animal Care.

\section{Pharmacologic Immunosuppressive Therapy}

Pharmacologic immunosuppressive therapy (PI) is detailed in Table 1. 


\section{Removal of Anti-Pig Antibody}

Antibody depletion from the nonhuman primate was achieved by extracorporeal immunoadsorption (EIA) by either (a) hemoperfusion through a pig liver or an immunoaffinity column of Gal trisaccharide type 6 (Alberta Research Council, Edmonton, Canada) for 60 minutes, or (b) apheresis using a COBE-Spectra pheresis system (Blood Component Technology, Inc., Lakewood, Colorado), with plasma perfusion through an Gal column (three plasma volumes). Details of these procedures have been described previously by Kozlowski et al (1998).

\section{Experimental Groups and Tolerance Induction Regimens}

Four groups of animals were studied (Table 1), distinguished by the type of induction regimens they received. Group $1(n=4)$ underwent EIA on Day 0 and received CyA and DSG, but did not undergo a tolerance induction regimen.

Group 2 ( $n=12)$ underwent a nonmyeloablative tolerance induction regimen pretransplant, followed by EIA, porcine bone marrow (BM) infusion, and kidney transplantation on Day 0 . The nonmyeloablative regimen consisted of (a) whole body irradiation (WBI) (300cGy) (Day -6 or Day -3$)$, (b) thymic irradiation (TI) (700cGy) (Day -1), (c) splenectomy (Day -6 or Day 0), (d) antithymocyte globulin (ATG) (ATGAM, Upjohn Company, Kalamazoo, Michigan) given intravenously at $50 \mathrm{mg} / \mathrm{kg} /$ day for three consecutive days (Days $-3,-2$, and -1 ), and (e) porcine BM transplantation on Day 0 . Details of this regimen have been described previously (Kozlowski et al, 1999; Sablinski et al, 1995, 1997). EIA was performed on Day 0, immediately before BM infusion and kidney transplantation; CyA and DSG were administered until graft rejection.

Group $3(n=4)$ underwent the nonmyeloablative tolerance induction regimen (described above) more than 20 days before kidney transplantation. The white blood cell (WBC) count (including CD2 + T and NK cells) in the peripheral blood decreased after induction regimens, but recovered close to the pre-induction level by Days 20 to 27 (Kozlowski et al, 1999). Porcine $\mathrm{BM}$ infusion and kidney transplantation were performed on Day 0 and were combined with EIA, CyA, and DSG.

Group $4(n=5)$ received autologous BM, which was transduced with either a retroviral vector containing the swine leukocyte antigen (SLA) Class II DR gene or the neomycin-resistance gene. The transduced BM was infused four months before porcine kidney transplantation was performed using a donor matched for the Class II gene. Before the infusion of the autologous $\mathrm{BM}$, one baboon (B77-13) underwent the nonmyeloablative induction regimen (as in Group B). The other four baboons received myeloablative WBI (900cGy). This latter protocol did not include TI or ATG but did include a course of SCR1 $(n=4)$ or CVF $(n=1)$ administered until the kidney was rejected. Engraftment of the BM occurred on Days 18 to 21. Approxi- mately four months later, splenectomy and porcine kidney transplantation was performed on Day 0 , combined with EIA, CyA, and DSG. Details of this regimen have been described previously (lerino et al, 1998).

\section{Histological and Immunohistochemical Examination}

For light microscopic examination, tissue was fixed in $10 \%$-buffered formalin and embedded in paraffin. Sections were examined after hematoxylin and eosin (H\&E) and periodic acid-Schiff (PAS) staining.

For electron microscopic studies, tissue was fixed in $2.5 \%$ glutaraldehyde in phosphate buffer $(\mathrm{pH} \mathrm{7.4)}$ and postfixed with $1 \%$ osmium tetroxide, dehydrated, and embedded in Epon 812. Ultrathin sections were stained with lead citrate and examined with a Phillips 301 electron microscope.

For immunofluorescence studies for the detection of deposition of immunoglobulin, complement, and fibrin, frozen tissue sections were stained by the direct immunofluorescent technique (Leventhal et al, 1993; Lin et al, 1998), using fluorescein isothiocyanate (FITC)-conjugated rabbit polyclonal antibody to human IgG, IgM, C3, and fibrinogen (all from DAKO, Carpinteria, California). Rabbit anti-human albumin (DAKO) was used as control. In order to examine the correlation between graft injury and antibody deposition, immunohistochemistry for detection of $\operatorname{lgM}$ and IgG was also performed in paraffin-embedded tissue sections, using the standard avidin-biotin-horseradishperoxidase complex (ABC) technique reported elsewhere (Meehan et al, 1997). After being deparaffinized and incubated with trypsin for 12 minutes at $37{ }^{\circ} \mathrm{C}$, sections were incubated with rabbit anti-human IgG (A090, DAKO) or IgM (A091, DAKO) followed by a biotin-labeled goat anti-rabbit lgG (Vector, Burlingame, California), ABC (Vector), and hydrogen peroxide $\left(\mathrm{H}_{2} \mathrm{O}_{2}\right)$ containing 3,3'-diaminobendizine (DAB) (Research Genetics, Hansville, Alabama). No difference in immunopathological findings was observed between the immunofluorescence and immunoperoxidase techniques, although the relatively extensive deposition of $\lg G$ and IgM seen in immunoperoxidase staining may be associated with the differing sensitivities of the two methods.

Tissue for immunohistochemistry staining to identify the phenotype of infiltrating cells was examined by the $\mathrm{ABC}$ technique in frozen sections, using antibodies against human CD3 (rabbit polyclonal anti-human CD3, DAKO), CD8 (DK25, DAKO, or Leu 2a; Becton Dickinson, San Jose, California), CD4 (Leu 3a, Becton Dickinson), CD68 (KP-1, DAKO), and GMP-17 (TIA-1; Coulter Immunology, Hialeah, Florida), and antirhesus monkey NK cell antibody (N42) (Gengozian et al, 1992). To examine the correlation between graft injury and cell infiltrate, CD3+, GMP-17+, or CD68+ cells were stained by the $A B C$ technique in paraffinembedded tissue sections. Double immunostaining with CD3 and GMP-17 for the identification of cytotoxic $T$ cells was performed in formalin-fixed paraffin sections by using a two-color staining technique (Meehan et al, 1997). First, the sections were stained with a mouse monoclonal antibody to GMP-17 and 
incubated with alkaline phosphatase-labeled antimouse IgG (OEM concept, Grafelfing, Germany) with a blue reaction product (Alkaline Phosphatase Substrate Kit III, Vector). Sections were then stained with a rabbit polyclonal antibody to CD3, HRP-labeled anti-rabbit IgG (OEM concept), hydrogen peroxide $\left(\mathrm{H}_{2} \mathrm{O}_{2}\right)$ containing 3,3'-diaminobendizine (DAB) (Research Genetics) (brown reaction product). The ABC technique, using biotin-labeled Griffonia (Bandeiraea) simplicifolia Isolectin B4 (GS-IB4, Vector), was employed to detect Gal expressed on pig vascular endothelial cells (Oriol et al, 1993).

Aggregation of platelets was identified by the expression of CD62P, which was stained by the $A B C$ method in frozen sections, using anti-human CD62P (Becton Dickinson). Although activated endothelial cells also express CD62P, this antibody does not cross-react with pig tissues or cells (data not shown). The expression of CD62P in the renal xenografts, therefore, indicated the aggregation of cynomolgus monkey or baboon platelets.

In histological sections, damaged nuclear DNA associated with apoptosis was labeled by the terminal deoxynucleotidyl transferase (TdT)-mediated dUTPbiotin nick-end labeling (TUNEL) method (Gavrieli et al, 1992). After being deparaffinized and incubated with proteinase $\mathrm{K}(100 \mathrm{~g} / \mathrm{ml})$ for 15 minutes, sections were rinsed in TdT buffer and incubated with TdT 1:25 and biotinylated-dUTP 1:20 in TdT buffer for 60 minutes at $37{ }^{\circ} \mathrm{C}$. The biotinylated nuclei were detected with avidin-peroxidase and $\mathrm{H}_{2} \mathrm{O}_{2}$ containing DAB. Controls for immunohistochemistry or the TUNEL method included substitution of the primary antibody with an irrelevant murine monoclonal antibody or omission of the dUTP or TdT, respectively.

\section{Quantification of Histological Findings}

Morphometric studies were performed to determine the number of infiltrating GMP-17+ polymorphonuclear leukocytes (PMNs), GMP-17+ mononuclear cells (MNCs) and CD68+ cells, and frequency of TUNEL + damaged cells in the peritubular capillaries or the peritubular interstitium (both intracapillary and peritubular interstitial compartments combined), glomeruli, tubules, and arteries. The results were calculated as the average number of GMP-17+ PMNs, GMP-17+ MNCs, CD68+ cells or TUNEL + cells per grid area in the tubules, peritubular capillaries or peritubular interstitium, or glomerular or arterial crosssections.

For the evaluation of $\operatorname{lgM}$ deposition or CD62P+ platelet aggregation, each glomerulus or each grid area was graded semiquantitatively using a graded system reported by others (Zachem et al, 1997; Shihab et al, 1995): Grade 0, no localized increase in staining; Grade 1, little increase in staining (deposition in 2 or 3 glomerular or peritubular capillaries); Grade 2, moderate increase in staining (involving $<25 \%$ of the glomerular or peritubular capillaries); Grade 3, intense increase in staining (involving $<50 \%$ of capillaries); and Grade 4, maximal increase in staining ( $>50 \%$ capillary involvement). Deposition of IgM or CD62P deposition in arteries was determined by the percentage of arteries affected.

More than 40 fields of renal cortex (at $400 \times$, using an optical grid area of $0.0625 \mathrm{~mm}^{2}$ ), more than 40 glomerular cross-sections, and all arterial crosssections in all fields of the renal cortex were counted in each kidney sample without prior knowledge of the clinical or histologic findings. Counts were expressed as the numbers of positive cells per $\mathrm{mm}^{2}$, as the number of positive cells per glomerular or arterial cross-section, or as the percentage of the arteries involved. Since the pattern of graft injury was similar whether the recipient was cynomolgus monkey or baboon, the results have been combined. Results were expressed as the mean, and correlation between data was assessed by Pearson's method.

\section{Acknowledgements}

The authors wish to thank Ms. Patricia Della Pelle for expert technical assistance and our many colleagues at both the Massachusetts General Hospital and Bio Transplant, Inc., who have contributed towards the studies reported in this paper.

\section{References}

Auchincloss HJ (1994). Cell-mediated xenoresponses: Strong or weak? Clin Transplant 8:155-159.

Bach FH, Winkler H, Ferran C, Hancock WW, and Robson SC (1996). Delayed xenograft rejection. Immunol Today 17:379385.

Ballermann BJ (1998). Endothelial cell activation. Kidney Int 53:1810-1826.

Bartholomew A, Cosimi AB, Sachs DH, Bilin M, Boskovic S, Colvin R, Hong $H$, Johnson M, Kimikawa M, Leguern A, Meehan S, Sablinski T, Wee SL, and Powelson J (1997). A study of tolerance in a concordant xenograft model. Transplant Proc 29:923-924.

Blakely ML, Van der Werf WJ, Berndt MC, Dalmasso AP, Bach FH, and Hancock WW (1994). Activation of intragraft endothelial and mononuclear cells during delayed xenograft rejection. Transplantation 58:1059-1066.

Candinas D, Belliveau S, Koyamada N, Miyatake T, Hechenleitner P, Mark W, Bach FH, and Hancock WW (1996). T cell independence of macrophage and natural killer cell infiltration, cytokine production, and endothelial activation during delayed xenograft rejection. Transplantation 62:1920-1927.

Collins AB, Schneeberger EE, Pascual MA, Saidman SL, Williams WW, Tolkoff-Rubin N, Cosimi AB, and Colvin RB (1999). Complement activation in acute humoral renal allograft rejection: Diagnostic significance of C4d deposits in peritubular capillaries. J Am Soc Nephrol 10:2208-2214.

Colvin RB (1995). General features of the allograft response. In: Colvin RB, Bhan AK, and McCluskey RT, editors. Diagnostic immunopathology, 2nd ed. New York: Raven, 311328.

Colvin RB (1996). The renal allograft biopsy. Kidney Int 50:1069-1082. 
Cooper DKC, Ye Y, Rolf LL, and Zuhdi N (1991). The pig as potential organ donor for man. In: Cooper DKC, Kemp E, Reemtsma K, and White DJG, editors. Xenotransplantation. Heidelberg: Springer, 481-500.

Daniels LJ and Platt JL (1997). Hyperacute xenograft rejection as an immunologic barrier to xenotransplantation. Kidney Int Suppl 58:S28-S35.

Fryer JP, Chen S, Johnson E, Simone P, Sun LH, Goswitz JJ, and Matas AJ (1997). The role of monocytes and macrophages in delayed xenograft rejection. Xenotransplantation 4:40-48.

Gavrieli Y, Sherman Y, and Ben-Sasson SA (1992). Identification of programmed cell death in situ via specific labeling of nuclear DNA fragmentation. J Cell Biol 119:493-501.

Gengozian N, Good RA, and Fu SM (1992). Development and characterization of monoclonal antibodies to lymphocyte cell surface antigens of the rhesus monkey. Transplantation 53:1306-1312.

Good AH, Cooper DKC, Malcolm AJ, Ippolito RM, Koren E, Neethling FA, Ye Y, Zuhdi N, and Lamontagen LR (1992). Identification of carbohydrate structures that bind human antiporcine antibodies: Implications for discordant xenografting in humans. Transplant Proc 24:559-562.

Hancock WW (1997). Beyond hyperacute rejection: Strategies for development of pig-primate xenotransplantation. Kidney Int Suppl 58:S36-S40.

lerino FL, Kozlowski T, Siegel JB, Shimizu A, Colvin RB, Banerjee PT, Cooper DKC, Cosimi AB, Bach FH, Sachs DH, and Robson SC (1998). Disseminated intravascular coagulation in association with the delayed rejection of pig-tobaboon renal xenografts. Transplantation 66:1439-1450.

Kobayashi T, Taniguchi S, Neethling FA, Rose AG, Hancock WW, Ye Y, Niekrasz M, Kosanke S, Wright LJ, White DJ, and Cooper DKC (1997). Delayed xenograft rejection of pig-tobaboon cardiac transplants after cobra venom factor therapy. Transplantation 64:1255-1261.

Kozlowski T, lerino FL, Lambrigts D, Foley A, Andrews D, Awwad M, Monroy R, Cosimi AB, Cooper DKC, and Sachs DH (1998). Depletion of anti-Gal1-3Gal antibody in baboons by specific $\alpha \mathrm{Gal}$ immunoaffinity columns. Xenotransplantation 5:122-131.

Kozlowski T, Shimizu A, Lambrigts D, Yamada K, Fuchimoto Y, Glaser R, Monroy R, Xu Y, Awwad M, Colvin RB, Cosimi AB, Robson SC, Fishman J, Spitzer TR, Cooper DKC, and Sachs DH (1999). Porcine kidney and heart transplantation in baboons undergoing a tolerance induction regimen and antibody adsorption. Transplantation 67:18-30.

Lambrigts D, Sachs DH, and Cooper DKC (1998). Discordant organ xenotransplantation in primates, World experience and current status: Transplantation 66:547-561.

Lawson JH and Platt JL (1996). Molecular barriers to xenotransplantation. Transplantation 62:303-310.

Leventhal JR, Matas AJ, Sun LH, Reif S, Bolman RM 3rd, Dalmasso AP, and Platt JL (1993). The immunopathology of cardiac xenograft rejection in the guinea pig-to-rat model. Transplantation 56:1-8.

Lin SS, Weidner BC, Byrne GW, Diamond LE, Lawson JH, Hoopes CW, Daniels LJ, Daggett CW, Parker W, Harland RC, Davis RD, Bollinger RR, Logan JS, and Platt JL (1998). The role of antibodies in acute vascular rejection of pig-tobaboon cardiac transplants. J Clin Invest 101:1745-1756.
Meehan SM, McCluskey RT, Pascual M, Preffer FI, Anderson P, Schlossman ST, and Colvin RB (1997). Cytotoxicity and apoptosis in human renal allografts: Identification, distribution, and quantitation of cells with a cytotoxic granule protein GMP-17 (TIA-1) and cells with fragmented nuclear DNA. Lab Invest 76:639-649.

Mundle SD (1995). The two in situ techniques do not differentiate between apoptosis and necrosis but rather reveal distinct patterns of DNA fragmentation in apoptosis. Lab Invest 72:611-612.

Oriol R, Ye Y, Koren E, and Cooper DKC (1993). Carbohydrate antigens of pig tissues reacting with human natural antibodies as potential targets for hyperacute vascular rejection in pig-to-man organ xenotransplantation. Transplantation 56:1433-1442.

Palmetshofer A, Galili U, Dalmasso AP, Robson SC, and Bach FH (1998). Galactosyl epitope-mediated activation of porcine aortic endothelial cells: Type II activation. Transplantation 65:971-978.

Robson SC, Siegel JB, Lesnikoski BA, Kopp C, Candinas UR, and Bach FH (1996). Aggregation of human platelets induced by porcine endothelial cells is dependent upon both activation of complement and thrombin generation. Xenotransplantation 3:24-34.

Saadi S, Holzknecht RA, Patte CP, Stern DM, and Platt JL (1995). Complement-mediated regulation of tissue factor activity in endothelium. J Exp Med 182:1807-1814.

Sablinski T, Gianello PR, Bailin M, Bergen KS, Emery DW, Fishman JA, Foley A, Hatch T, Hawley RJ, Kozlowski T, Lorf T, Meehan S, Monroy R, Powelson JA, Colvin RB, Cosimi AB, and Sachs $\mathrm{DH}$ (1997). Pig to monkey bone marrow and kidney xenotransplantation. Surgery 121:381-391.

Sablinski T, Latinne D, Gianello P, Bailin M, Bergen K, Colvin RB, Foley A, Hong HZ, Lorf $T$, Meehan S, Monroy R, Powelson JA, Sykes M, Tanaka M, Cosimi AB, and Sachs DH (1995). Xenotransplantation of pig kidneys to nonhuman primates: I. Development of the model. Xenotransplantation 2:264-270.

Sachs DH (1994). The pig as a potential xenograft donor. Vet Immunol Immunopathol 43:185-191.

Sachs DH and Sablinski T (1995). Tolerance across discordant xenogeneic barriers. Xenotransplantation 2:234-239.

Seebach JD and Waneck GL (1997). Natural killer cells in xenotransplantation. Xenotransplantation 4:201-211.

Sharabi Y, Aksentijevich I, Sundt TM 3rd, Sachs DH, and Sykes M (1990). Specific tolerance induction across a xenogeneic barrier: Production of mixed rat/mouse lymphohematopoietic chimeras using a nonlethal preparative regimen. $J$ Exp Med 172:195-202.

Shihab FS, Yamamoto T, Nast CC, Cohen AH, Nobel NA, Gold LI, and Border WA (1995). Transforming growth factor- $\beta$ and matrix protein expression in acute and chronic rejection of human renal allografts. Am J Soc Nephrol 6:286-294.

Shimizu A, Yamada K, Meehan SM, Sachs DH, and Colvin RB. (1997a). Intragraft cellular events associated with tolerance in pig allografts: The acceptance reaction. Transplant Proc 29:1155.

Shimizu A, Yamada K, Sachs DH, and Colvin RB. (1997b). Progressive to chronic rejection vs tolerance in pig renal allografts (Abstract). J Am Soc Nephrol 8:667. 
Sykes M, Lee LA, and Sachs DH (1994). Xenograft tolerance. Immunol Rev 141:245-276.

Trpkov K, Campbell P, Pazderka F, Cockfield S, Solez K, and Halloran PF (1996). Pathologic features of acute renal allograft rejection associated with donor-specific antibody. Transplantation 61:1586-1592.

Yamada K, Seebach J, DerSimonian H, and Sachs DH (1996). Human anti-pig T-cell mediated cytotoxity. Xenotransplantation 3:179-187.
Zachem CR, Alpers CE, Way W, Shankland SJ, Couser WG, and Johnson RJ (1997). A role for P-selectin in neutrophil and platelet infiltration in immune complex glomerulonephritis. J Am Soc Nephrol 8:1838-1844. 